\title{
Chemistry and Isotopic Composition of Ground Water Along a Section Near the Newmark Area, San Bernardino County, California
}

By John A. Izbicki, Wesley R. Danskin, and Gregory O. Mendez

\section{U.S. GEOLOGICAL SURVEY}

Water-Resources Investigations Report 97-4179

Prepared in cooperation with the

U.S. ENVIRONMENTAL PROTECTION AGENCY

N
సิ
டீ

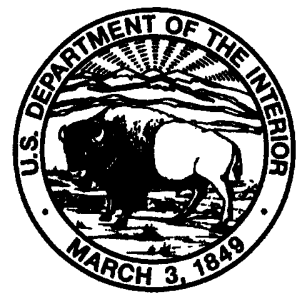




\section{U.S. DEPARTMENT OF THE INTERIOR BRUCE BABBITT, Secretary}

U.S. GEOLOGICAL SURVEY

Thomas J. Casadevall, Acting Director

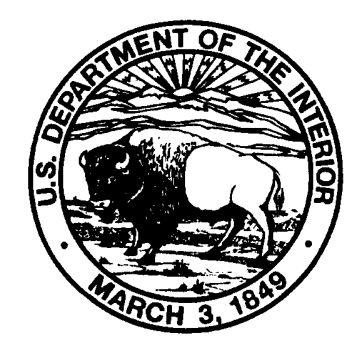

The use of firm, trade, and brand names in this report is for identification purposes

only and does not constitute endorsement by the U.S. Geological Survey.

For addtional information write to:

Copies of this report can be purchased from:

District Chief

U.S. Geological Survey

Placer Hall

$6000 \mathrm{~J}$ Street

Sacramento, CA 95819-6129
U.S. Geological Survey

Information Services

Box 25286

Denver Federal Center

Denver, CO 80225 


\section{CONTENTS}

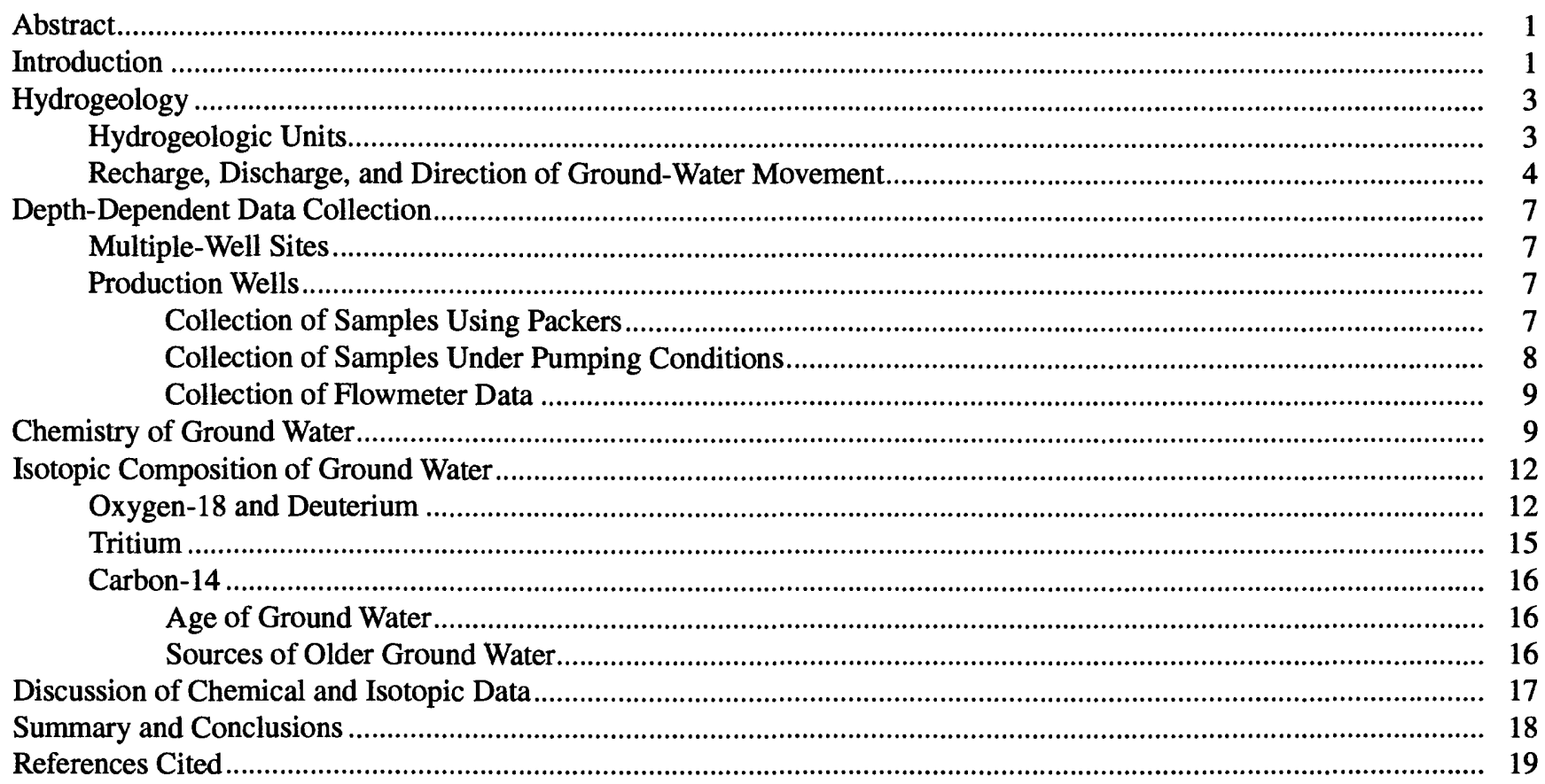

\section{FIGURES}

1. Map showing location of study area and selected wells and surface-water sites, San Bernardino County, California

2. Hydrogeologic section $A-A^{\prime}$ in the San Bernardino area of southern California

3. Graphs showing electric logs, vertical flowrate, well construction, and sample-collection depths for selected wells in the San Bernardino area of southern California

4. Diagram showing major-ion composition of water from selected wells in the San Bernardino area of southern California

5. Hydrogeologic section showing major-ion composition of water from wells along section $A-A^{\prime}$ in the San Bernardino area of southern California

Boxplots showing concentrations of selected constituents by group for selected wells in the San Bernardino area of southern California

7. Graph showing delta deuterium $(\delta \mathrm{D})$ as a function of delta oxygen-18 $\left(\delta^{18} \mathrm{O}\right)$ for water samples from

selected wells in the San Bernardino area of southern California ....................................................................... Hydrogeologic section showing isotopic (deuterium, tritium, carbon-13, and carbon-14) composition of water from selected wells along section $A-A^{\prime}$ in the San Bernardino area of southern California.....

\section{TABLES}

1. Data for selected wells in the San Bernardino area of southern California

2. Chemical and isotopic analyses of water from selected wells in the San Bernardino area of southern California 
CONVERSION FACTORS, VERTICAL DATUM, ABBREVIATIONS, AND WELLNUMBERING SYSTEM

\begin{tabular}{rcl}
\hline Multiply & By & To obtain \\
\hline inch (in.) & 25.4 & millimeter \\
foot (ft) & 0.3048 & meter \\
foot per day (ft/d) & 0.3048 & meter per day \\
gallon per minute $(\mathrm{gal} / \mathrm{min})$ & 0.003785 & cubic meter per minute \\
mile $(\mathrm{mi})$ & 1.609 & kilometer \\
square mile $\left(\mathrm{mi}^{2}\right)$ & 2.590 & square kilometer \\
pound (lb) & 0.4536 & kilogram \\
\hline
\end{tabular}

Temperature is given in degrees Fahrenheit $\left({ }^{\circ} \mathrm{F}\right)$, which can be converted to degrees Celsius $\left({ }^{\circ} \mathrm{C}\right)$ by the following equation:

$$
{ }^{\circ} \mathrm{C}=5 / 9\left({ }^{\circ} \mathrm{F}-32\right)
$$

\section{VERTICAL DATUM}

Sea level: In this report, "sea level" refers to the National Geodetic Vertical Datum of 1929 (NGVD of 1929)—a geodetic datum derived from a general adjustment of the first-order level nets of both the United States and Canada, formerly called Sea Level Datum of 1929.

\section{ABBREVIATIONS}

$\mathrm{mg} / \mathrm{L} \quad$ milligram per liter

$\mu \mathrm{g} / \mathrm{L} \quad$ microgram per liter

$\mathrm{kg} \quad$ kilogram

$\mu \mathrm{S} / \mathrm{cm} \quad$ microseimen per centimeter at $25^{\circ} \mathrm{C}$

per mil parts per thousand, as used with delta $(\delta)$ notation

$\mathrm{pC} / \mathrm{L}$ picocurie per liter

RI/FS Remedial Investigation/Feasibility Study

USEPA United States Environmental Protection Agency

UCM upper confining member

UWB upper water-bearing unit

MCM middle confining member

MWB middle water-bearing unit

LCM lower confining member

LWB lower water-bearing unit

MCL maximum contaminant level

SMCL secondary maximum contaminant level

VSMOW Vienna Standard Mean Ocean Water 


\section{WELL-NUMBERING SYSTEM}

Wells are identified and numbered according to their location in the rectangular system for the subdivision of public lands. The identification consists of the township number, north or south; the range number, east or west; and the section number. Each section is further divided into sixteen 40 -acre tracts lettered consecutively (except I and $\mathrm{O}$ ), beginning with ' $\mathrm{A}$ ' in the northeast corner of the section and progressing in a sinusoidal manner to ' $R$ ' in the southeast corner. Within the 40-acre tract, wells are sequentially numbered in the order they are inventoried. The final letter refers to the base line and meridian. In California, there are three base lines and meridians; Humboldt (H), Mount Diablo (M), and San Bernardino (S). All wells in the study area are referenced to the San Bernardino base line and meridian (S). Well numbers consist of 15 characters and follow the format 001S004W22L017S. In this report, well numbers are abbreviated and written 1S/4W-22L17. Wells in the same township and range are referred to only by their section designation, 22L17. The following diagram shows how the number for well $1 \mathrm{~S} / 4 \mathrm{~W}-22 \mathrm{~L} 17$ is derived.

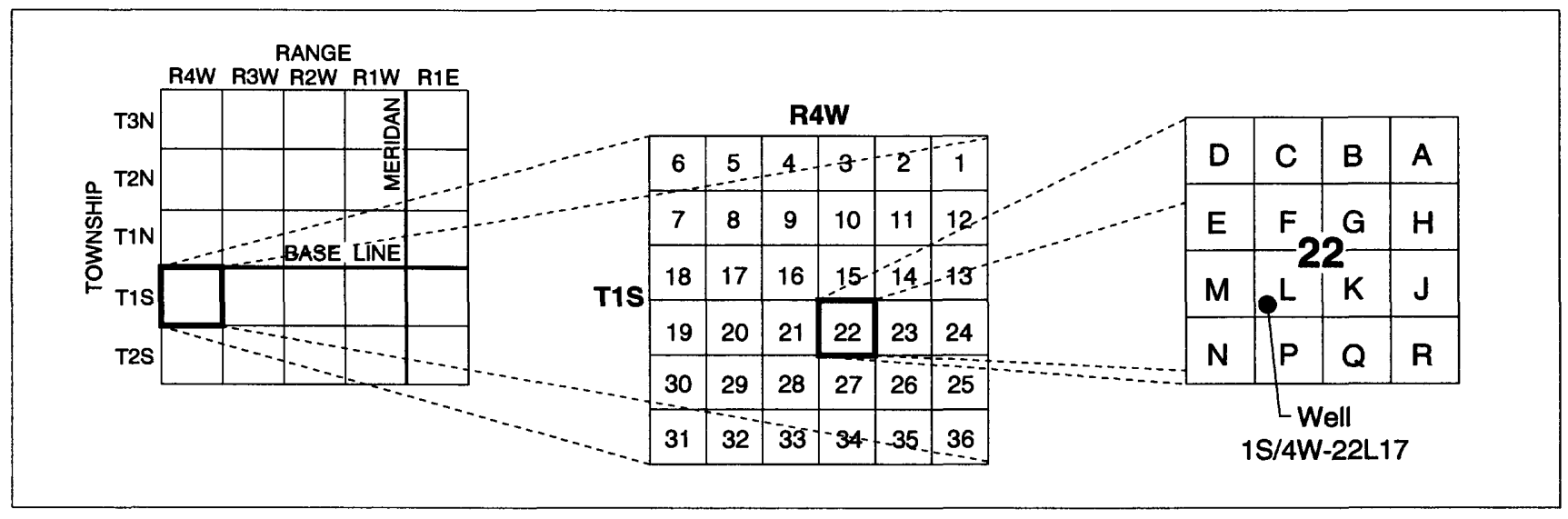

Well-numbering diagram 


\title{
Chemistry and Isotopic Composition of Ground Water Along a Section near the Newmark Area, San Bernardino County, California
}

\author{
By John A. Izbicki, Wesley R. Danskin, and Gregory O. Mendez
}

\section{ABSTRACT}

Chemical and isotopic analyses and flowmeter measurements in pumped wells were used to determine the source, movement, and age of ground water along a section of the valley-fill aquifer from the San Jacinto Fault to the base of the San Bernardino Mountains near the Newmark area in the Bunker Hill Basin of southern California. Water samples were collected from four multipledepth well sites, from different depths within three production wells, and from two nearby streams; these samples were analyzed for major ions, selected trace elements, stable isotopes of oxygen and hydrogen (delta oxygen-18 and delta deuterium), tritium, and carbon- 14 . Within the production wells, variations in vertical flowrate with depth were recorded during pumped conditions using a standard spinner tool. Where saturated, the upper 200 feet of unconsolidated deposits contributed as much as 60 percent of the well discharge; deposits at depths greater than 700 feet contributed less than 10 percent. Chemical analyses indicate that three general zones of ground-water quality are present along a north-south section-an oxygenated zone near the base of the San Bernardino Mountains, an oxygen-depleted zone near the San Jacinto Fault, and a deeper zone characterized by concentrations of fluoride greater than $1 \mathrm{mg} / \mathrm{L}$ and by a general water-quality composition similar to that of base flow in East Twin Creek. The presence of tritium in water from wells along the section indicates that post-1952 recharge has moved rap- idly through the valley-fill aquifer to depths as great as 800 feet. Carbon-14 data indicate that the maximum age of ground water, sampled at depths ranging from 600 to 1,000 feet, is less than 5,000 years before present. Ground water along the study section is much younger than ground water from similar depths in other nearby basins. Delta oxygen-18 and delta deuterium data indicate that as much as 25 percent of the discharge from some wells near the base of the San Bernardino Mountains is water that was imported from northern California. Improved knowledge of depth-dependent ground-water flow along this section can aid in the design of an effective strategy for basin management, including remediation of the Newmark area, which is designated by the U.S. Environmental Protection Agency as a Superfund cleanup site.

\section{INTRODUCTION}

Ground water pumped from the Bunker Hill Basin, about 60 mi east of Los Angeles, is a major source of supply for the cities of San Bernardino, Redlands, and Riverside, and for the surrounding agricultural areas (fig. 1; the city of Riverside is outside the map area, about 15 mi southwest of San Bernardino). In 1980, the California Department of Health Services discovered chlorinated solvents in public-supply wells near the Shandin Hills in the Bunker Hill Basin. In 1990, the U.S. Environmental Protection Agency (USEPA) began a Remedial Investigation/Feasibility Study (RI/FS) in the area of this contamination, which was designated the Newmark Ground Water Contami- 
nation Superfund Site, Newmark Operable Unit. The present study resulted from efforts by USEPA to better understand the ground-water flow system in the vicinity of the Newmark Operable Unit and to design a successful remediation strategy.

During the past 90 years, the hydrogeology of the Bunker Hill Basin has been studied extensively with respect to surface-water runoff, ground-water supply, liquefaction, and land subsidence. However, a detailed appraisal of ground-water chemistry-in particular, isotopic chemistry - with depth has not been done. This information is needed to better understand the three-dimensional movement of ground water, to design an effective remediation strategy for the New-

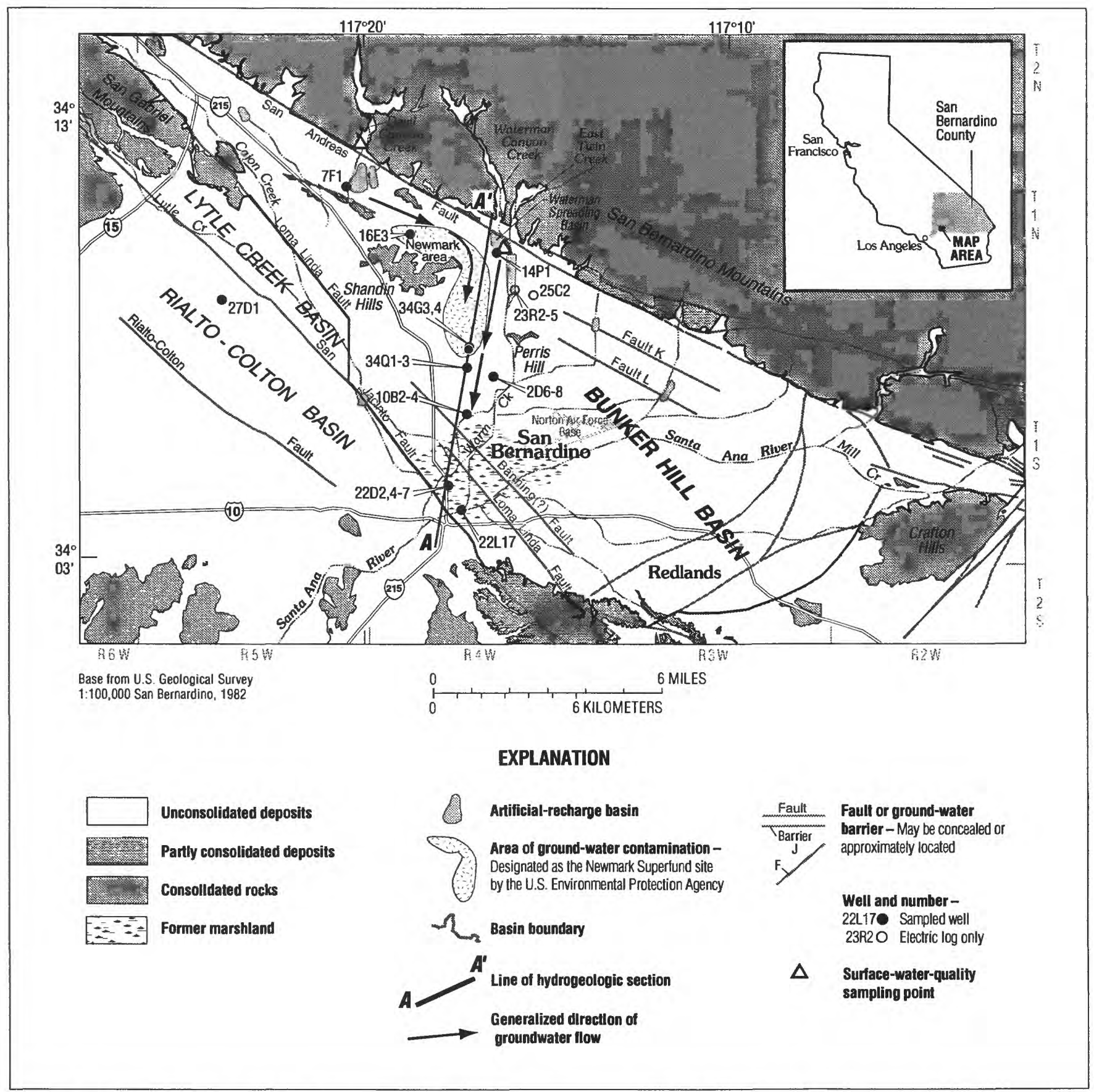

Figure 1. Location of study area and selected wells and surface-water sites, San Bernardino County, California. 
mark contamination site, and to develop basinwide water-management plans involving recharge and pumpage.

The study described in this report was funded by the USEPA to determine the chemistry and isotopic composition of ground water with depth along a section through the Newmark area. The data were used to evaluate the source, movement, and age of ground water in different saturated hydrogeologic units within the valley-fill aquifer along a north-south section across the Bunker Hill Basin. Evaluation of chlorinated organic solvents along the section was beyond the scope of this study.

In concurrent field and computer simulation studies in the Bunker Hill Basin, researchers are investigating the occurrence and movement of ground water in the valley-fill aquifer. These researchers will benefit from a detailed geochemical and isotopic study of the aquifer, especially if the water-quality data are collected from known depths and are representative of specific hydrogeologic units within the valley-fill aquifer.

The authors thank Michael H. Lowe of the City of San Bernardino Water Department and Eugene P. McMeans of the Riverside-Highland Water District for providing access to production wells for collection of water-quality samples and flowmeter data. The authors also thank the URS Corporation for providing access to USEPA observation wells and for their assistance with sample collection from those wells. The authors gratefully acknowledge the efforts of William R. Providence (deceased) of Layne-Christensen, Inc., for his assistance with sample collection during packer tests.

\section{HYDROGEOLOGY}

The Bunker Hill ground-water basin is a sediment-filled structural trough between the San Andreas and San Jacinto Faults in the upper part of the Santa Ana River Basin near the base of the San Bernardino Mountains. The climate of this $120-\mathrm{mi}^{2}$ area is Mediterranean, with warm, dry summers and cool, wet winters. Average annual precipitation ranges from about 12 in. on the valley floor to more than 28 in. in the nearby mountains.

\section{Hydrogeologic Units}

Valley-fill sediment in the basin generally consists of unconsolidated alluvial fan deposits derived from the surrounding mountains and hills. These deposits interfinger with river-channel deposits, primarily from the Santa Ana River and Lytle Creek, and with freshwater marsh deposits associated with ground-water discharge near the San Jacinto Fault. On the basis of driller's logs and water-level data for about 880 wells, Dutcher and Garrett (1963) divided the valley-fill sediment into upper, middle, and lower zones. Each zone includes a fine-grained, less permeable hydrogeologic unit overlying a coarse-grained, more permeable hydrogeologic unit (fig. 2). The fine-grained units restrict vertical ground-water flow and, where underlying deposits are saturated, act as confining layers. The valley-fill sediment is underlain by a bedrock complex of igneous and metamorphic rocks similar to those found in Shandin Hills and Crafton Hills.

The hydrogeologic units described above form the conceptual framework used by Hardt and Hutchinson (1980) in the first ground-water flow model of the Bunker Hill and adjacent Lytle Creek basins. This division, with slight modifications, remains the conceptual framework for current studies of the occurrence and movement of ground water and is depicted in section $A-A^{\prime}$ (fig. 2). Data for wells shown in section $A-A^{\prime}$ or sampled as part of this study are given in table 1 .

The upper water-bearing unit (UWB in fig. 2) consists of boulders, gravel, and sand near the base of the mountains and grades to finer grained sand, silt, and clay near the San Jacinto Fault. Along section $A-A^{\prime}$, the UWB is about $200 \mathrm{ft}$ thick and includes an approximate 125 - $\mathrm{ft}$ thickness of river-channel deposits along the Santa Ana River (Dutcher and Garrett, 1963). In many areas of the basin, the highly permeable materials of the UWB probably account for most of the horizontal flow simulated in the upper layer of the ground-water flow model developed by Hardt and Hutchinson (1980). Near the base of the San Bernardino Mountains, however, the UWB was mostly unsaturated during 1995-96 when data were collected for this study.

Near the San Jacinto Fault, the UWB is overlain by a near-surface, fine-grained deposit that ranges in thickness from about 50 to $100 \mathrm{ft}$. This deposit, known as the upper confining member (UCM, not shown in fig. 2), is areally extensive except where it has been 


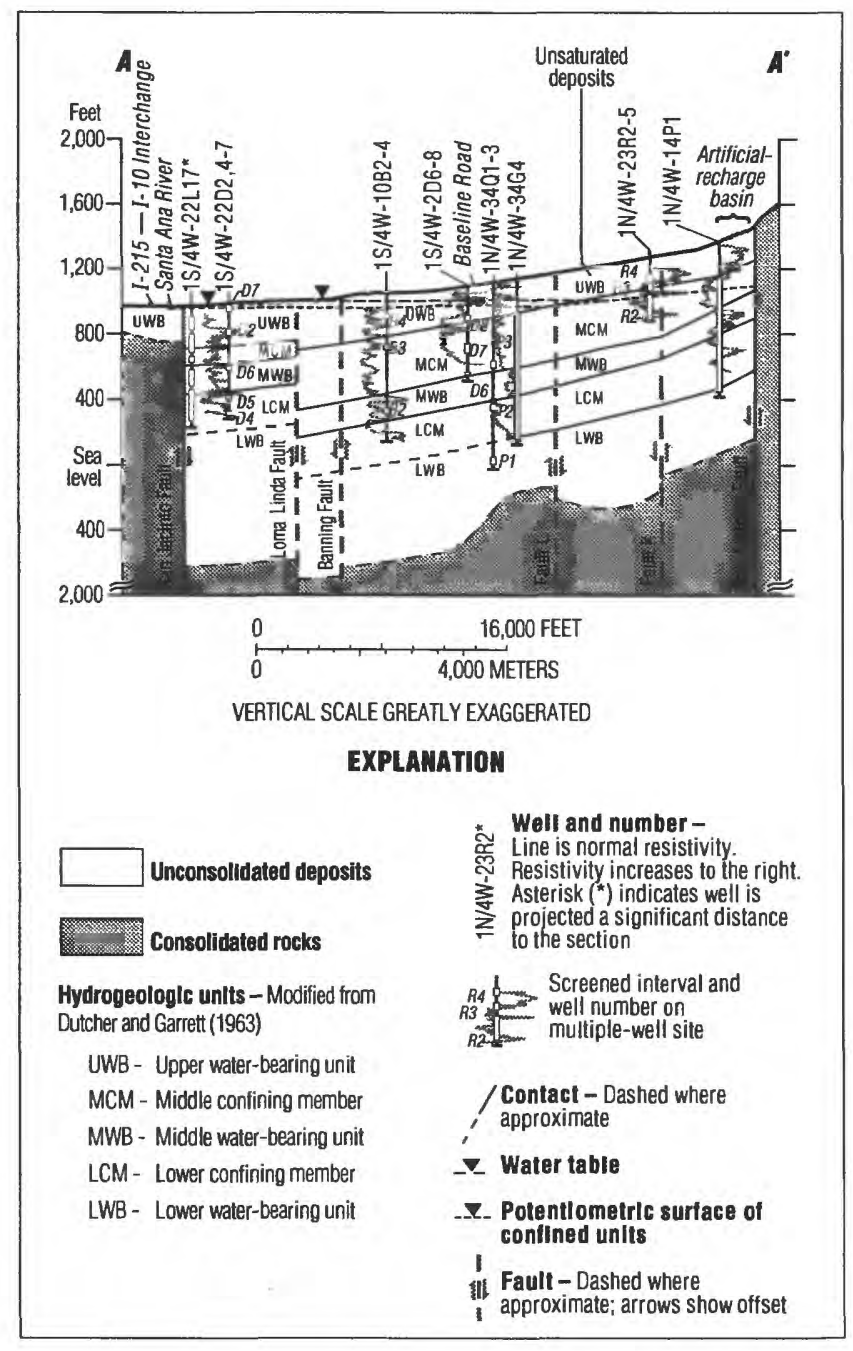

Figure 2. Hydrogeologic section $A-A^{\prime}$ in the San Bernardino area of southern California.

eroded by streams - primarily the Santa Ana River and Lytle Creek - and has been replaced with coarsegrained, river-channel deposits. Where present in the former marshland, the UCM has a low vertical hydraulic conductivity and confines underlying ground water. Water from the UCM was sampled at well $1 \mathrm{~S} / 4 \mathrm{~W}$ -22D7 (fig. 2). Away from the former marshland toward the San Bernardino Mountains, the UCM is mostly unsaturated and is overlain by a shallow coarse-grained unit. This overlying unit also is unsaturated and was not sampled as part of this study. Because of the thinness of both the UCM and shallow coarse-grained unit, neither is shown in figure 2 .
The middle confining member (MCM) is heterogeneous, but consists mostly of fine-grained layers underlying the UWB. As described by Dutcher and Garrett (1963), the MCM has generally low permeability and is capable of confining deeper ground water. The MCM is the hydrogeologic unit (confining bed) that is simulated as restricting flow between the upper and lower layers of the ground-water flow model developed by Hardt and Hutchinson (1980). Near the base of the mountains, the MCM is coarse grained, and changes in ground-water levels (hydraulic heads) with depth are small. Some sand and gravel layers within the MCM are areally extensive and highly permeable. On the basis of flowmeter and water-quality data, which are discussed later in this report, these layers can yield large quantities of water to wells. During sampling for this study (1995-96), as much as $100 \mathrm{ft}$ of the MCM was unsaturated near the base of the San Bernardino Mountains (fig. 2).

The middle water-bearing unit (MWB) lies beneath the MCM and is composed of mostly wellsorted gravel and sand layers interbedded in places with silt and clay layers. The MWB, along with the permeable layers in the MCM, probably accounts for most of the horizontal flow simulated in the lower layer of the ground-water flow model developed by Hardt and Hutchinson (1980).

The lower water-bearing unit (LWB) and lower confining member (LCM), which directly underlie the MWB, were defined by Dutcher and Garrett (1963) as consisting of silty gravel and silty sand layers and interbedded silt and clay layers. The LCM has a greater percentage of fine-grained sediment than does the LWB. Only a few wells in the basin are sufficiently deep to penetrate the lower hydrogeologic units (LCM and LWB). As a result, the thickness and areal variations in the lower units are not known precisely. On the basis of flowmeter and water-quality data, discussed later in this report, the LCM and the LWB do not yield large quantities of water to wells.

\section{Recharge, Discharge, and Direction of Ground-Water Movement}

Within the basin, ground water flows generally from recharge areas along the base of the San Bernardino Mountains, through the valley-fill aquifer, to dis- 
Table 1. Data for selected wells in the San Bernardino area of southern California

[CR, City of Rialto; CSB, City of San Bernardino; EVWD, East Valley Water District; RHWD, Riverside-Highland Water District; SBVMWD, San Bernardino Valley Municipal Water District; USEPA, U.S. Environment Protection Agency; nd, not determined]

\begin{tabular}{|c|c|c|c|c|c|c|}
\hline $\begin{array}{l}\text { State well } \\
\text { number }\end{array}$ & Owner & Other well identifiers & $\begin{array}{l}\text { Latitude/ } \\
\text { longitude }\end{array}$ & $\begin{array}{l}\text { Original } \\
\text { depth } \\
\text { (feet) }\end{array}$ & $\begin{array}{l}\text { Open Intervals } \\
\text { below land surface } \\
\text { (feet) }\end{array}$ & $\begin{array}{c}\text { Water- } \\
\text { quality } \\
\text { group } \\
\text { number } \\
\text { (fig. 4) }\end{array}$ \\
\hline \multicolumn{7}{|c|}{ Wells sampled for water quality during this study } \\
\hline 1N/4W-7F1 & CSB & $\begin{array}{l}\text { Devil Canyon 2, } \\
3600711\end{array}$ & $\begin{array}{l}34^{\circ} 11^{\prime} 22^{\prime \prime} \\
117^{\circ} 20^{\prime} 26^{\prime \prime}\end{array}$ & 450 & $177-292,306-316,356-400$ & 1 \\
\hline $1 \mathrm{~N} / 4 \mathrm{~W}-14 \mathrm{P} 1$ & CSB & $\begin{array}{l}\text { 40th \& Valencia, } \\
3603472\end{array}$ & $\begin{array}{l}34^{\circ} 9^{\prime} 55^{\prime \prime} \\
117^{\circ} 16^{\prime} 20^{\prime \prime}\end{array}$ & 940 & $220-920$ & 3 \\
\hline $1 \mathrm{~N} / 4 \mathrm{~W}-16 \mathrm{E} 3$ & CSB & $\begin{array}{l}\text { Newmark \#3, } \\
3600716\end{array}$ & $\begin{array}{l}34^{\circ} 10^{\prime} 19^{\prime \prime} \\
117^{\circ} 18^{\prime} 42^{\prime \prime}\end{array}$ & 495 & $\begin{array}{l}232-270,283-305,331-462, \\
480-490\end{array}$ & 1 \\
\hline 1N/4W-34G3 & CSB & $\begin{array}{l}\text { 16th \& Sierra Way, } \\
3600726\end{array}$ & $\begin{array}{l}34^{\circ} 7^{\prime} 44^{\prime \prime} \\
117^{\circ} 17^{\prime \prime}\end{array}$ & 712 & $490-680$ & 1 \\
\hline 1N/4W-34G4 & CSB & $\begin{array}{l}\text { 17th \& Sierra Way \#2, } \\
3603208\end{array}$ & $\begin{array}{l}34^{\circ} 7^{\prime} 47^{\prime \prime} \\
117^{\circ} 17^{\prime} 5^{\prime \prime}\end{array}$ & 1,005 & $210-990$ & 1,3 \\
\hline 1N/4W-34Q1 & USEPA & MW-11-C & $\begin{array}{l}34^{\circ} 7^{\prime} 19^{\prime \prime} \\
117^{\circ} 17^{\prime \prime}\end{array}$ & 1,264 & $1,070-1,100$ & 3 \\
\hline 1N/4W-34Q2 & USEPA & MW-11-B & $\begin{array}{l}34^{\circ} 7^{\prime} 19^{\prime \prime} \\
117^{\circ} 17^{\prime \prime}\end{array}$ & 1,264 & $770-800$ & 1 \\
\hline $1 \mathrm{~N} / 4 \mathrm{~W}-34 \mathrm{Q} 3$ & USEPA & MW-11-A & $\begin{array}{l}34^{\circ} 7^{\prime} 19^{\prime \prime} \\
117^{\circ} 17^{\prime \prime} 8^{\prime \prime}\end{array}$ & 1,264 & $510-540$ & 1 \\
\hline 1S/4W-2D6 & SBVMWD & $09-240$ & $\begin{array}{l}34^{\circ} 7^{\prime} 7^{\prime \prime} \\
117^{\circ} 16^{\prime} 25^{\prime \prime}\end{array}$ & 530 & $520-530$ & 2 \\
\hline $1 \mathrm{~S} / 4 \mathrm{~W}-2 \mathrm{D} 7$ & SBVMWD & $09-238$ & $\begin{array}{l}34^{\circ} 7^{\prime} 7^{\prime \prime} \\
117^{\circ} 16^{\prime} 25^{\prime \prime}\end{array}$ & 400 & $340-400$ & 1 \\
\hline 1S/4W-2D8 & SBVMWD & 09-239 & $\begin{array}{l}34^{\circ} 7^{\prime} 7^{\prime \prime} \\
117^{\circ} 16^{\prime} 25^{\prime \prime}\end{array}$ & 190 & $170-190$ & 2 \\
\hline 1S/4W-10B2 & SBVMWD & $\# 1$ & $\begin{array}{l}34^{\circ} 6^{\prime} 15^{\prime \prime} \\
117^{\circ} 17^{\prime} 8^{\prime \prime}\end{array}$ & 700 & $680-700$ & 1 \\
\hline 1S/4W-10B3 & SBVMWD & $\# 2,09-237$ & $\begin{array}{l}34^{\circ} 6^{\prime} 15^{\prime \prime} \\
117^{\circ} 17^{\prime \prime} 8^{\prime \prime}\end{array}$ & 320 & $300-320$ & 1 \\
\hline $1 \mathrm{~S} / 4 \mathrm{~W}-10 \mathrm{~B} 4$ & SBVMWD & $\# 3,09-236$ & $\begin{array}{l}34^{\circ} 6^{\prime} 15^{\prime \prime} \\
117^{\circ} 17^{\prime \prime} 8^{\prime \prime}\end{array}$ & 120 & $100-120$ & 2 \\
\hline 1S/4W-22D2 & SBVMWD & Vault \#1 & $\begin{array}{l}34^{\circ} 4^{\prime} 39^{\prime \prime} \\
117^{\circ} 7^{\prime} 39^{\prime \prime}\end{array}$ & 200 & $160-200$ & 2 \\
\hline $1 \mathrm{~S} / 4 \mathrm{~W}-22 \mathrm{D} 4$ & SBVMWD & Vault \#3 & $\begin{array}{l}34^{\circ} 4^{\prime} 39^{\prime \prime} \\
117^{\circ} 7^{\prime} 39^{\prime \prime}\end{array}$ & 655 & $650-655$ & 3 \\
\hline 1S/4W-22D5 & SBVMWD & Vault \#4 & $\begin{array}{l}34^{\circ} 4^{\prime} 39^{\prime \prime} \\
117^{\circ} 7^{\prime} 39^{\prime \prime}\end{array}$ & 574 & $555-574$ & 2 \\
\hline 1S/4W-22D6 & SBVMWD & Vault \#2 & $\begin{array}{l}34^{\circ} 4^{\prime} 39^{\prime \prime} \\
117^{\circ} 7^{\prime} 39^{\prime \prime}\end{array}$ & 398 & $388-398$ & 2 \\
\hline 1S/4W-22D7 & SBVMWD & Vault \#5 & $\begin{array}{l}34^{\circ} 4^{\prime} 39^{\prime \prime} \\
117^{\circ} 7^{\prime} 39^{\prime \prime}\end{array}$ & 55 & $10-20,35-45$ & 2 \\
\hline $1 \mathrm{~S} / 4 \mathrm{~W}-22 \mathrm{~L} 17$ & RHWD & FW5, 3603514 & $\begin{array}{l}34^{\circ} 4^{\prime} 6^{\prime \prime} \\
117^{\circ} 17^{\prime} 18^{\prime \prime}\end{array}$ & 640 & $\begin{array}{l}80-110,130-240,260-280 \\
380-420,460-510,520-630\end{array}$ & 2,3 \\
\hline
\end{tabular}


Table 1. Data for selected wells in the San Bernardino area of southern California-Continued

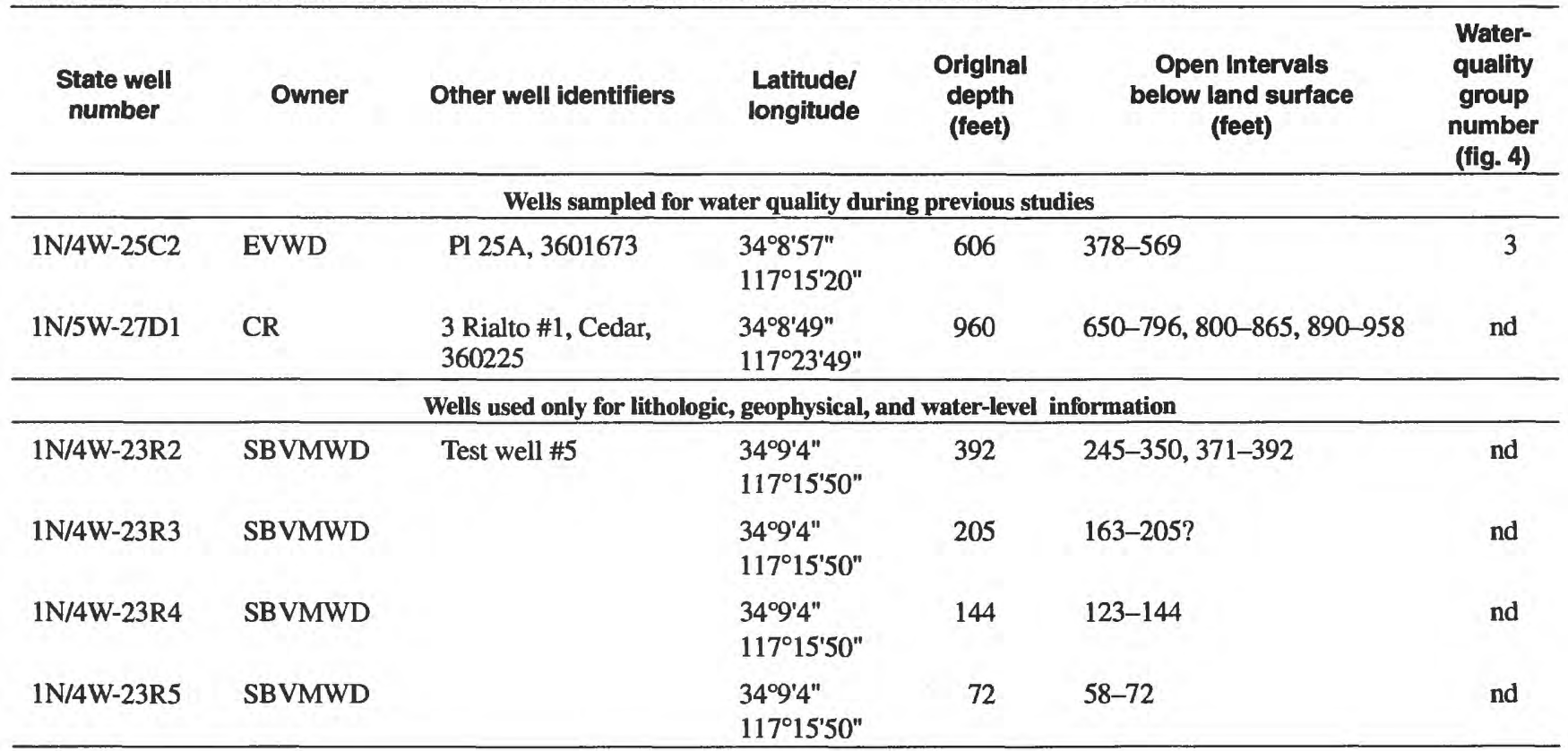

charge areas near the San Jacinto Fault. Prior to about 1945 , most ground water discharged as upward flow to a freshwater marshland adjacent to the San Jacinto Fault, as flow rising into the Warm Creek channel, or as underflow to the Rialto-Colton Basin through permeable materials in the vicinity of the Santa Ana River. After 1945, ground-water pumpage near the San Jacinto Fault increased, the marshlands dried, and ground-water discharge into Warm Creek decreased to near zero. Presently (1996), ground-water discharge in the Bunker Hill Basin is mostly to wells, and the vertical hydraulic gradient beneath the former marshland-from the water table to the potentiometric surface of confined units (fig. 2)-indicates a downward movement of ground water.

Section $A-A^{\prime}$ was drawn, on the basis of waterlevel data, to approximate a ground-water flow path through the valley-fill aquifer from the base of the San Bernardino Mountains to the San Jacinto Fault. Along this section near the mountains, ground-water recharge occurs primarily as infiltration of streamflow from Devil Canyon, Waterman Canyon, and East Twin Creeks. Flow in these streams is diverted into artificialrecharge basins, where it infiltrates and recharges the underlying valley-fill aquifer. In recent years, imported water from northern California also has been released into the artificial-recharge basins to augment recharge of native runoff. Two wells (1N/4W-7F1 and 1N/4W16E3) near Devil Canyon Creek were sampled to aid in differentiating recharge from the creek and recharge from imported water. Data from these wells were projected onto section $A-A^{\prime}$.

Movement of ground water along section $A-A^{\prime}$ is affected by several faults that restrict flow. Typically, the restriction is minimal in the shallow, recently deposited sediment (UWB) and increases in deeper, older units (MCM, MWB). The most important faults with respect to ground-water flow are the San Jacinto and Loma Linda Faults. A more complete description of faults within the Bunker Hill Basin and their effect on ground-water flow is given by Dutcher and Garrett (1963) and Hardt and Hutchinson (1980).

Along the north half of section $A-A^{\prime}$, ground water moves along a relatively well-defined flow path that passes between Shandin Hills and Perris Hill, as indicated by the shape of the Newmark contaminant plume (fig. 1). Along the south half of section $A-A^{\prime}$, ground-water flow is more complex. The pattern of dominant recharge in the basin-from the Santa Ana River and Mill Creek east of section $A-A^{\prime}$ and from Lytle Creek west of section $A-A^{\prime}-$ creates groundwater flow paths that are oblique to the section, especially in the vicinity of the former marshland (Hardt and Hutchinson, 1980; Hardt and Freckleton, 1987). Additional study would be necessary to define these flow paths areally and with depth. Also, pumping from wells on either side of section $A-A^{\prime}$ induces ground water to flow obliquely with respect to the section 
(Earth Technology Corporation, 1993). Despite these unquantified lateral effects on ground-water flow caused by recharge and pumping, section $A-A^{\prime}$ is an excellent location for geochemical analysis because the section represents one of the most uniform flow paths within the Bunker Hill Basin.

\section{DEPTH-DEPENDENT DATA COLLECTION}

Depth-dependent chemical and isotopic data were collected from observation and production wells along section $A-A^{\prime}$ (fig. 2) using several different techniques; and, as a result, different methods of interpretation were required. Observation wells sampled as part of this study had short screened intervals, typically less than $20 \mathrm{ft}$, and were open to only one hydrogeologic unit. At multiple-depth well sites, each observation well is completed at a different depth. In contrast, production wells generally have long screened intervals, commonly greater than $500 \mathrm{ft}$, and are open to more than one hydrogeologic unit. For any well that is open to a single hydrogeologic unit, sample collection and interpretation is a straight-forward process. Most production wells, however, produce water that is a mixture of ground water from different hydrogeologic units. For these wells, special sample-collection techniques and methods of interpretation were used to obtain depth-dependent data.

\section{Multiple-Well Sites}

At four multiple-well sites (1S/4W-22D2, 4-7; 1S/4W-10B2-4; 1S/4W-2D6-8; and 1N/4W-34Q1-3), depth-dependent samples were collected from 14 existing observation wells. Each of these wells has a relatively short screened interval that is positioned next to a small part of the valley-fill aquifer. During construction, the annulus of each well was filled with sand opposite the well screen and with much-less-permeable material elsewhere. Water levels and water samples collected from these wells, therefore, are assumed to represent ground water at the depth of the well screen.

Prior to sample collection, most wells were developed using an air compressor to ensure that the well screen was open to the aquifer and that a large volume of ground water was removed from the well. To prevent possible contamination of wells installed as part of the RI/FS (1N/4W-34Q1-3), these wells were not developed using an air compressor. These wells, however, are only a few years old and are believed to be open to the aquifer. During sample collection, all observation wells were purged using stainless-steel, positive-displacement pumps to ensure that sampled water was representative of aquifer conditions. Purging was continued until at least three casing volumes of ground water had been extracted or until measurement of field properties (temperature, specific conductivity, and $\mathrm{pH}$ ) stabilized.

\section{Production Wells}

The water-quality and water-yielding characteristics of different layers of the valley-fill aquifer penetrated by a well combine to affect the overall quality of water produced from the well. Two techniques were used to obtain depth-dependent data from production wells and to minimize the influence of different layers of the aquifer. These techniques either isolate production from each zone of interest using packers, or provide a combination of depth-dependent samples and flowmeter data collected under pumping conditions. When using the latter technique, both types of information are needed to estimate the chemistry of water contributed from each zone.

\section{Collection of Samples Using Packers}

At one production well (1S/4W-22L17), inflatable packers were used to isolate water from four different depths within the well (fig. 3). These packers-which can be deflated, moved vertically within the well casing, and reinflated-commonly are used to isolate different parts of a well and obtain depth-dependent samples (Driscoll, 1986). Once the packers in well 1S/4W-22L17 were securely in place, the isolated interval was pumped, using a small submersible pump, at about $75 \mathrm{gal} / \mathrm{min}$ for 4 to 11 hours depending on the depth and length of the interval. Deeper and wider intervals were pumped longer to remove larger volumes of water. The normal production rate for the well using a turbine pump is about $1,400 \mathrm{gal} / \mathrm{min}$. Packer tests are a commonly used sampling technique that is based on the assumption that water pumped from each interval represents ground water from that depth in the aquifer. Data collected in this study, however, show that this assumption was not valid for well 1S/4W-22L17 and may not be valid for other gravel-packed wells in alluvial aquifers. 


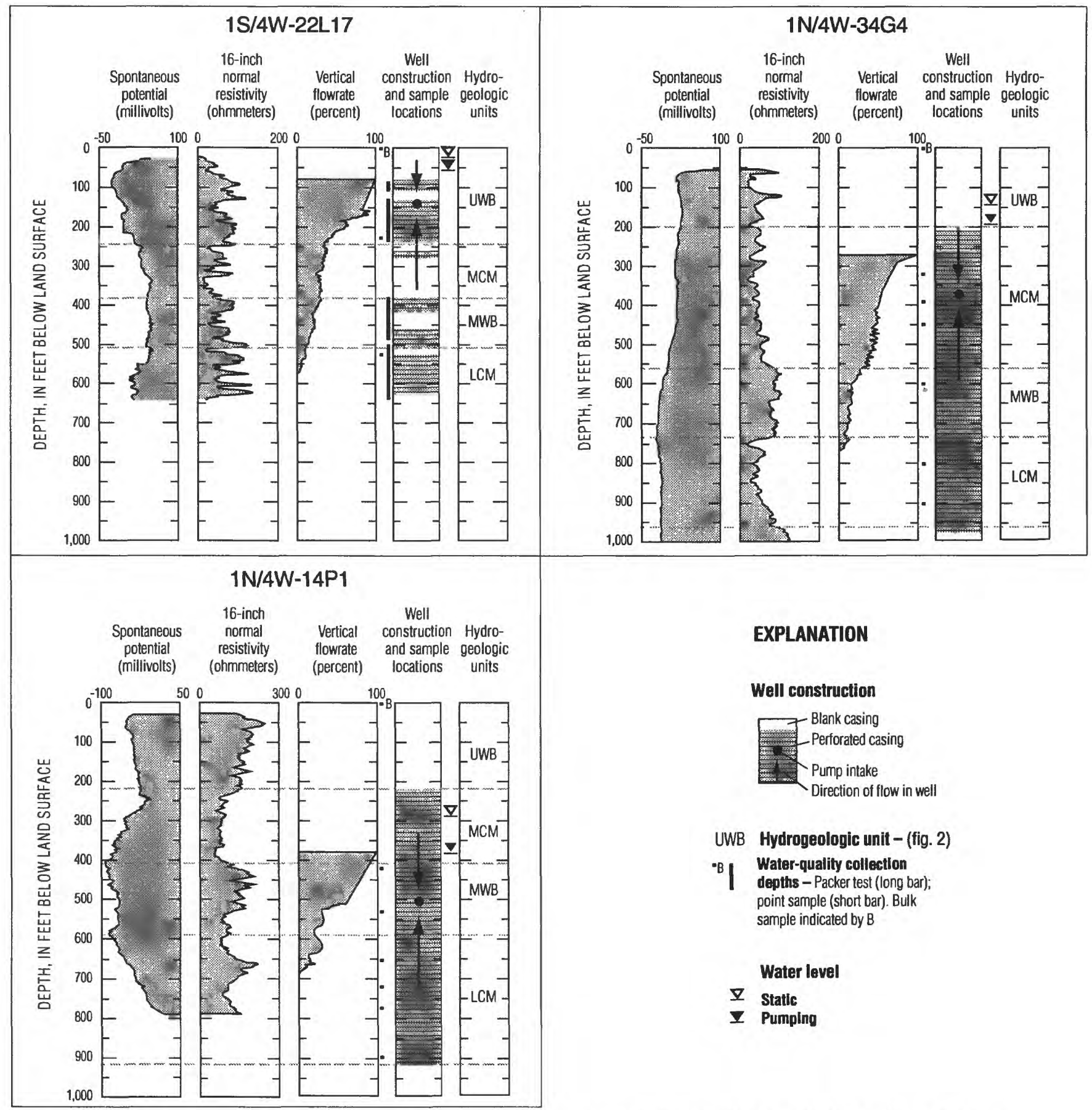

Figure 3. Electric logs, vertical flowrate, weli construction, and sample-collection depths for selected wells in the San Bernardino area of southern California.

\section{Collection of Samples Under Pumping Conditions}

At two production wells (1N/4W-34G4 and 1N/ 4W-14P1), packers were not used. Instead, water samples were collected under pumping conditions of 1,800 $\mathrm{gal} / \mathrm{min}$ and $285 \mathrm{gal} / \mathrm{min}$, respectively. Samples were collected from specific depths within the well using a high-pressure hose equipped with a one-way valve that allows water from a specific depth to enter the hose (Gossell and others, 1995). The hose then is retrieved from the well, and sample water is collected from the hose at the land surface. Prior to sample collection, each well was pumped for many hours to ensure that 
ground water was induced to enter the well throughout the entire screened interval. Pump intakes for wells 34G4 and 14P1 were set within the screened interval at depths of 375 and $507 \mathrm{ft}$, respectively (fig. 3).

Some samples were collected below the pump intake. In this case, the sample collected from the deepest part of the screened interval is interpreted as representative of water in the aquifer at that depth. Water sampled from the screened interval above that depth, but below the pump intake, is a mixture of water in the well at the first sample depth and water that entered the well between the two sample depths. The proportions of water in that mixture can be determined from flowmeter data, as discussed later in this report. This method of interpretation applies to all samples collected from the bottom of the well up to the pump intake.

For samples collected above the pump intake, the effect of mixing within the well is a mirror-image of what occurs below the pump intake. Water from the shallowest part of the well screen is interpreted as representative of water in the aquifer at that depth. Water sampled from the screened interval below that depth, but above the pump intake, is a mixture of water in the well at the shallowest sample depth and water that entered the well between the two sample depths. This method of interpretation applies to all samples collected from the top of the screened interval down to the pump intake.

\section{Collection of Flowmeter Data}

Flowmeter data were collected from three wells (1S/4W-22L17; 1N/4W-34G4; and 1N/4W-14P1) using commercially available vertical-axis current meters. This device, commonly referred to as a spinner tool, measures the velocity of water flowing inside the well casing by recording the number of revolutions per second of a spinning impeller. An increased velocity or flowrate is caused by progressively more water entering the well through the screened interval and is measured as more counts or revolutions per second, which are proportional to the increased flowrate. The flowmeter data are helpful in determining the water-yielding characteristics of aquifer material opposite the screened interval and in evaluating the mixtures of water collected at different depths within the well. Measurements at each well included a continuous profile of velocity collected for the entire depth of the well and static data (stop counts) collected approximately every $10 \mathrm{ft}$. Both kinds of data were used to prepare figure 3. Flowmeter data collected below the pump intake typically are more accurate than data collected above the intake.

Flowmeter data for the three wells show that water does not enter the wells uniformly with depth (fig. 3). For example, in well 1S/4W-22L17, about 65 percent of the water flowed in from the UWB, about 5 percent from the MCM, about 20 percent from the MWB, and about 10 percent from the LCM. These variations in water yield can be caused by differences in the hydraulic characteristics of adjacent aquifer materials, by unscreened intervals of casing, or by encrustation of the well screen.

Despite differences in well construction or the condition of the screened interval, analysis of the flowmeter data yielded general conclusions about flow from the valley-fill aquifer to production wells. The UWB, when saturated and adjacent to a well screen, contributes most of the water to a production well. The MCM, despite its overall fine-grained character, can yield large quantities of water to wells in the part of the Bunker Hill Basin north of the Loma Linda Fault. Data for well 1N/4W-34G4 (fig. 3) indicate that the UWB unit was unsaturated and that about 70 percent of the production came from the MCM. Individual layers of coarse-grained material within the $\mathrm{MCM}$, as thin as 25 $\mathrm{ft}$, contributed as much as $\mathbf{1 0}$ percent of the total well yield. The LCM contributed less than 10 percent of the water to each of the three wells.

\section{CHEMISTRY OF GROUND WATER}

Results of chemical analyses of 50 samples from 21 wells and 2 streams are given in table 2 , at back of report. On the basis of these data, water from wells sampled along section $A-A^{\prime}$ was fresh; the concentration of dissolved solids (residue on evaporation) ranged from 207 to $796 \mathrm{mg} / \mathrm{L}$. In general, dissolved-solids concentration was lower in water samples from recharge areas near the base of the San Bernardino Mountains and higher in water samples from discharge areas near the San Jacinto Fault.

The major-ion composition of water from sampled wells was evaluated using a Piper (trilinear) diagram. A Piper diagram (Piper, 1944) shows the relative contribution of major cations and anions, on a chargeequivalent basis, to the total ion content of the water. Percentage scales along the sides of the diagram indi- 


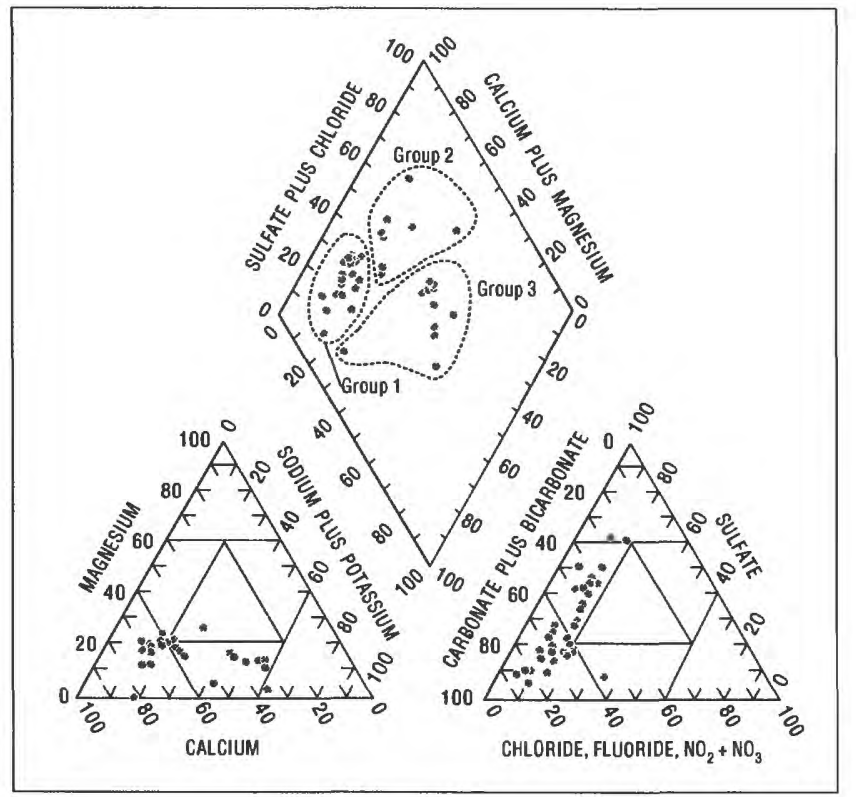

Figure 4. Major-ion composition of water from selected wells in the San Bernardino area of southern California. (Samples with similar water quality are identified as groups (1-3).

cate the relative concentration, in milliequivalents per liter, of each major ion. Cations are shown in the left triangle and anions are shown in the right triangle. The central diamond integrates the data. Given the $\mathrm{pH}$ of ground water in the Bunker Hill Basin, almost all the measured alkalinity is present as bicarbonate, and almost no carbonate ions are present. On the basis of major-ion data plotted on the Piper diagram shown in figure 4, water from wells sampled along section $A-A^{\prime}$ can be divided into three groups, each having different chemical compositions.

The major-ion composition of water in 22 samples from 7 wells was dominated by calcium and bicarbonate (fig. 4). For the purposes of this report, water from these wells is designated as group 1 water. Most of the wells yielding water within group 1 are located in the upgradient part of section $A-A^{\prime}$ near recharge areas (fig. 5). Water from wells within this group was oxygenated; dissolved-oxygen concentrations ranged from 0.6 to $9.2 \mathrm{mg} / \mathrm{L}$ (fig. 6). Iron and manganese concentrations were low, ranging from 3 to $140 \mu \mathrm{g} / \mathrm{L}$, and from 1 to $30 \mu \mathrm{g} / \mathrm{L}$, respectively. Fluoride concentrations also were low, ranging from 0.3 to $0.6 \mathrm{mg} / \mathrm{L}$. In contrast to these constituents, nitrate concentrations were relatively high, ranging from 0.24 to $6.7 \mathrm{mg} / \mathrm{L}$ as nitrogen, with a median value of almost $5 \mathrm{mg} / \mathrm{L}$. The Maximum Contaminant Level (MCL), as defined by the U.S. Environmental Protection Agency (1994), is

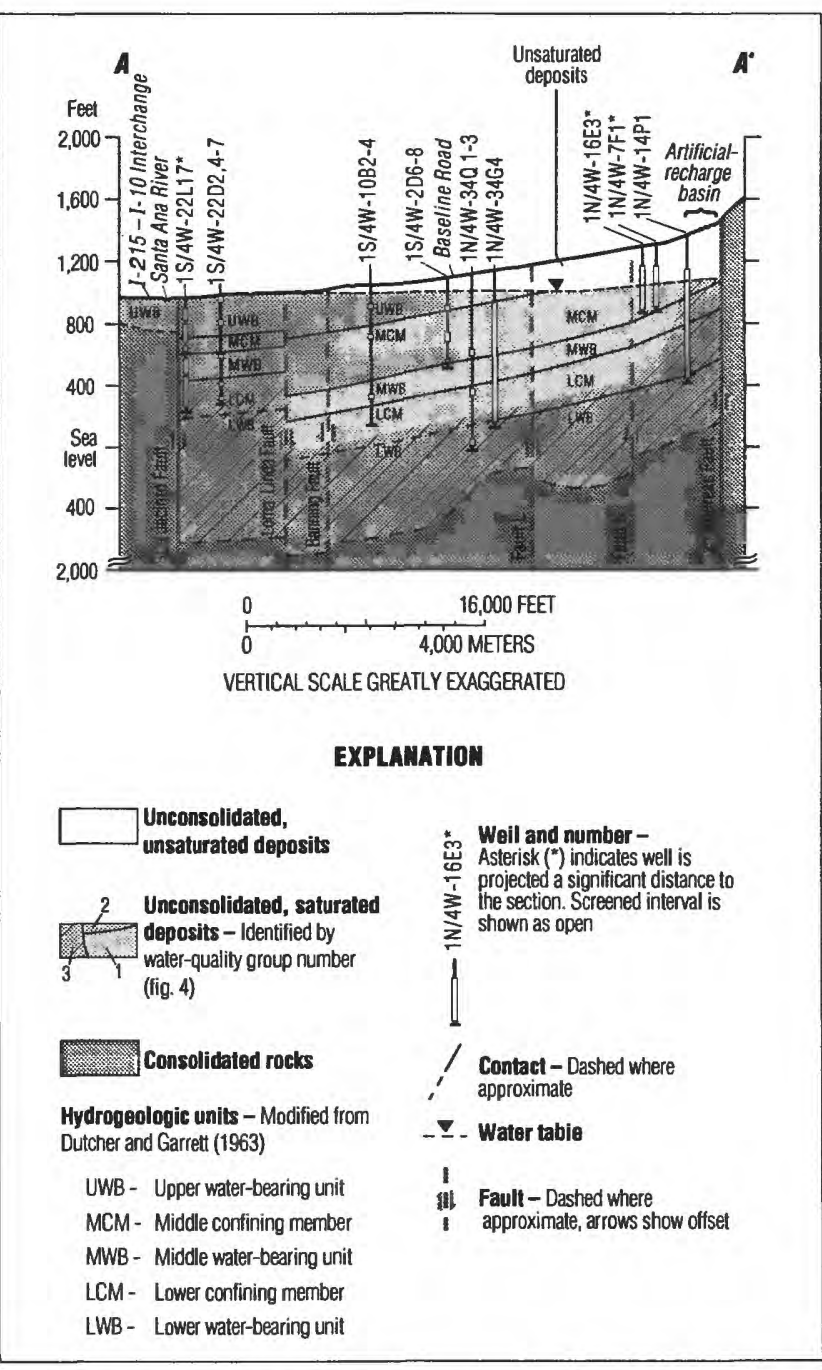

Figure 5. Major-ion composition of water from wells along section $A-A^{\prime}$ in the San Bernardino area of southern California.

$10 \mathrm{mg} / \mathrm{L}$ for nitrate as nitrogen. The occurrence and distribution of nitrate in the San Bernardino area and the relation of nitrate to land use have been studied by several researchers, including Klein and Bradford $(1979,1980)$, Eccles (1979), and Duell and Schroeder (1989).

The major-ion composition of water in group 1 samples from wells is similar to the composition of base flow sampled from Devil Canyon Creek near the base of the San Bernardino Mountains. The major-ion composition of water in group 1 also is similar to the composition of water from most wells sampled in the Bunker Hill Basin by Dutcher and Garrett (1963).

The major-ion chemistry of water in 16 samples from 7 wells was characterized by higher percentages of sodium and sulfate when compared to water in 

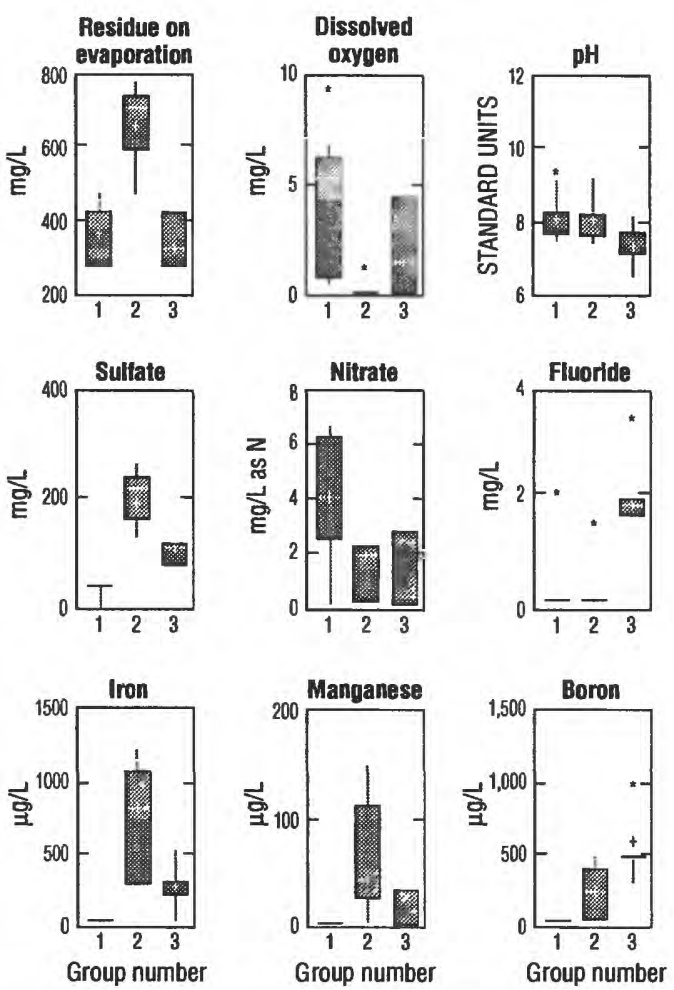

EXPLANATION

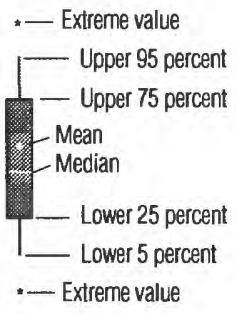

Figure 6. Concentrations of selected constituents by group for selected wells in the San Bernardino area of southern California.

group 1. For the purposes of this report, water from these wells is designated as group 2 water. These wells are located in the downgradient part of section $A-A^{\prime}$ near ground-water discharge areas along the San Jacinto Fault (fig. 5). In this area, sulfate concentrations ranged from 100 to $350 \mathrm{mg} / \mathrm{L}$, with a median concentration of $230 \mathrm{mg} / \mathrm{L}$. The Secondary Maximum Contaminant Level (SMCL), as defined by the U.S. Environmental Protection Agency (1994), for sulfate is $250 \mathrm{mg} / \mathrm{L}$. Mostly because of the higher concentrations of sodium and sulfate, water from wells in this area has higher dissolved-solids concentrations (ranging from 467 to $796 \mathrm{mg} / \mathrm{L}$ ) than does water from wells in the upgradient part of section $A-A^{\prime}$ (group 1 in fig. 6).
In the discharge area, dissolved-oxygen concentrations in water from most wells were less than the detection limit of $0.2 \mathrm{mg} / \mathrm{L}$. As a consequence of the low dissolved-oxygen concentrations, iron and manganese concentrations were high, ranging from 250 to $1,300 \mu \mathrm{g} / \mathrm{L}$, and from 10 to $160 \mu \mathrm{g} / \mathrm{L}$, respectively. The SMCL's are $300 \mu \mathrm{g} / \mathrm{L}$ for iron and $50 \mu \mathrm{g} / \mathrm{L}$ for manganese (U.S. Environmental Protection Agency, 1994). Fluoride concentrations, although higher than in group 1 , were low, ranging from less than 0.2 to $1.5 \mathrm{mg} / \mathrm{L}$. Nitrate concentrations were less than $2 \mathrm{mg} / \mathrm{L}$ as nitrogen in water from wells in this group, and one-third of the wells in this group yielded water having nitrate concentrations less than the detection limit of $0.05 \mathrm{mg} / \mathrm{L}$ as nitrogen. In contrast to water from group 1 , water from most wells near the discharge area and the site of the former marshland contained ammonia and other forms of reduced nitrogen.

The major-ion composition of water from wells in group 2 is similar to the composition of water from wells near the Santa Ana River that were sampled by Dutcher and Garrett (1963). They attributed differences in the composition of water from wells in this part of the basin to differences in the source of recharge water to the wells. Water from wells in group 2, however, could have evolved through chemical reactions between the aquifer materials and the calcium-carbonate water found in upgradient wells. For example, the differences in iron, manganese, and nitrogen species are consistent with low dissolved-oxygen concentrations that would be expected to result from the oxidation of organic material in freshwater marsh deposits. The increase in dissolved solids may be the result of the dissolution of minerals - in particular, sodium and sulfate salts formed by the evaporative discharge of ground water. These evaporite minerals commonly are found near the margins of marsh deposits in arid climates.

The major-ion chemistry of 12 samples from 3 wells was different from that of samples from other wells sampled in group 1 and group 2 . For the purposes of this report, water from these wells is designated as group 3 water. These wells are located in two general areas: (1) near the base of the San Bernardino Mountains, downgradient from recharge areas that receive water from East Twin Creek, and (2) in deeper parts of the ground-water flow system (fig. 5). The major-ion composition, and to some degree the trace-element composition, of water from these wells is similar to the 
composition of base flow sampled from East Twin Creek. Dissolved-oxygen concentrations of water from wells in group 3 ranged from $3.2 \mathrm{mg} / \mathrm{L}$ to less than the detection limit of $0.2 \mathrm{mg} / \mathrm{L}$. Ground water near the base of the mountains was oxygenated (figs. 5-6); farther from the mountains and deeper in the valley-fill aquifer, ground water does not contain oxygen. Iron and manganese concentrations increase with decreases in dissolved-oxygen concentrations and range from 13 to $510 \mu \mathrm{g} / \mathrm{L}$, and from less than 10 to $120 \mu \mathrm{g} / \mathrm{L}$, respectively. Fluoride concentrations were high, ranging from 1.1 to $3.2 \mathrm{mg} / \mathrm{L}$. The MCL used by the U.S. Environmental Protection Agency (1994) for fluoride is 4 $\mathrm{mg} / \mathrm{L}$, and the MCL used by the California Department of Health Services (as cited by U.S. Environmental Protection Agency, 1994) ranges from 1.4 to $2.4 \mathrm{mg} / \mathrm{L}$ depending on the average annual temperature. Nitrate concentrations were low, ranging from less than the detection limit of $0.05 \mathrm{mg} / \mathrm{L}$, to $2.6 \mathrm{mg} / \mathrm{L}$ as nitrogen. Ammonia and other reduced-nitrogen species were present in water from wells having low dissolvedoxygen concentrations.

The major-ion chemistry of water from group 3 wells (fig. 4) is similar to the composition of water from deep wells sampled by Dutcher and Garrett (1963). Water having this composition also was obtained by Duell and Schroeder (1989) from a well (1N/4W-25C2) that is near section $A-A^{\prime}$ and close to the base of the San Bernardino Mountains. They attributed the source of water from this well to recharge from East Twin Creek (Duell and Schroeder, 1989, p. 32).

The observed changes in ground-water chemistry with depth and with distance from the base of the mountains can be explained in three ways. First, ground water may have reacted with the matrix of the valley-fill aquifer. Sodium-carbonate water, for example, is not unusual in the downgradient parts of deep sedimentary aquifers in coastal California (Izbicki, 1991). Second, separate ground-water flow paths could be present-one with recharge water from East Twin Creek and the other with recharge water from Devil Canyon Creek. Ground water from each source might follow its own parallel, but separate flow path, maintaining its own distinct chemical composition as it moves from recharge to discharge areas. Third, ground water from other sources may be present in the deeper parts of section $A-A^{\prime}$.

These data suggest that because of chemical reactions that occur as water moves through an aquifer, chemical data alone are not sufficient to identify the source of water to wells or to track the movement of water through an aquifer. Therefore, isotopic data were collected to answer questions about the source and movement of ground water along section $A-A^{\prime}$ that could not be answered on the basis of ground-waterchemistry data alone.

\section{ISOTOPIC COMPOSITION OF GROUND WATER}

Isotopes are atoms of the same element, in which the nuclei of the atoms have the same number of protons but different numbers of neutrons. In this study, stable, naturally occurring isotopes of oxygen (oxygen18) and hydrogen (deuterium) were used to determine the source of ground water and to trace its movement along section $A-A^{\prime}$. Naturally occurring radioactive isotopes of hydrogen (tritium) and carbon (carbon-14) were used to determine the age (time since recharge) of the ground water. The presence of tritium was used to identify younger ground water (water recharged after 1952). Carbon-14 data were used to estimate the age of older ground water that did not contain tritium.

\section{Oxygen-18 and Deuterium}

Atoms of oxygen-18 $\left({ }^{18} \mathrm{O}\right)$ and deuterium $\left({ }^{2} \mathrm{H}\right)$ have more neutrons and a greater atomic mass (weight) than do the more common isotopes, oxygen-16 and hydrogen. This difference in weight results in differences in the physical and chemical behavior of the heavier, less abundant isotopes. Oxygen-18 and deuterium abundances are expressed as ratios, in delta notation $(\delta)$, as per mil (parts per thousand) differences, relative to the standard known as Vienna Standard Mean Ocean Water (VSMOW) (Gonfiantini, 1978). By convention, the value of VSMOW is 0 per mil. Oxygen$18\left(\delta^{18} \mathrm{O}\right)$ and deuterium $(\delta \mathrm{D})$ ratios relative to VSMOW can be measured more precisely than absolute abundances, and these ratios are useful in a wide variety of hydrologic studies (International Atomic Energy Agency, 1981). On the basis of duplicate analyses of samples collected as part of this and other studies, analytical precision is generally within 0.05 per mil for oxygen-18 and within 1.5 per mil for deuterium (Izbicki, 1996).

Most precipitation throughout the world originates from the evaporation of seawater. As a result, the 


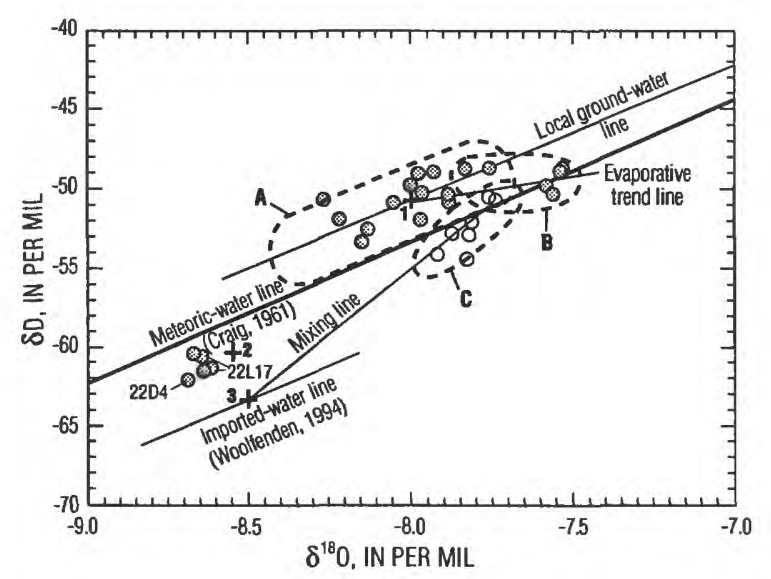

EXPLAMATION

Water-quality sample - Well number is given if discussed in text. Open circles are for well $34 G 4$ - 2217 0

Category of water-quallty samples

A Most wells sampled

B Shallow wells or wells with long screens open near the water table. Partly evaporated water shown in figure 8

Medlan composition of water quality samples

+1 Most wells sampled

+ 2 Santa Ana River (Woolfenden, 1994; Williams and Rodino, University of California Riverside, unpublished data)

+ 3 Imported water (Woolfenden, 1994; Coplen, U. S. Geological Survey, written communication, 1977)

C Isotopic composition varies with depth of sample in well $1 \mathrm{~N} / 4 \mathrm{~W}$ $34 \mathrm{G} 4$

Figure 7. Delta deuterium $(\delta \mathrm{D})$ as a function of delta oxygen$18\left(\delta^{18} \mathrm{O}\right)$ for water samples from selected wells in the San Bernardino area of southern California.

oxygen-18 $\left(\delta^{18} \mathrm{O}\right)$ and deuterium $(\delta \mathrm{D})$ composition of precipitation throughout the world is linearly correlated. This relation is expressed on a graph of $\delta^{18} \mathrm{O}$ and $\delta \mathrm{D}$ as the meteoric water line (Craig, 1961) (fig. 7). Over time, the isotopic composition of water vapor in different storms trends to an average value; therefore, the isotopic composition of ground water is determined primarily by local differences in the temperature of condensation of water vapor, prior to its being recharged in different places and at different times. Water that condenses at cooler temperatures (often associated with higher altitudes, cooler climatic regimes, or higher latitudes) is lighter (more negative) than water that condenses at warmer temperatures (often associated with lower altitudes, warmer climatic regimes, or lower latitudes). In addition, water that has been partly evaporated is enriched by fractionation of the heavier isotopes relative to its original composition. These values plot to the right of the meteoric water line along a line known as the evaporative trend line. As a result, the $\delta^{18} \mathrm{O}$ and $\delta \mathrm{D}$ composition of a water sample can provide a record of the source and evaporative history of the water. These differences in isotopic composition can be used as a tracer of the movement of the water.

The $\delta^{18} \mathrm{O}$ and $\delta \mathrm{D}$ composition of water from most wells sampled ( 14 samples from 9 wells shown as category $A$ in figure 7) ranged from -7.7 to -8.3 per mil, and from -49 to -53 per mil, respectively, and the median composition was about -8.0 and -50.7 per mil, respectively. Water within this relatively small range of composition was yielded by wells from all three groups identified on the basis of major-ion and other chemical data (fig. 8). The isotopic composition of water from wells in category A (fig. 7) plots along a local groundwater line about 3 per mil above, and parallel to, the meteoric water line. Similarly, water from wells in the adjacent Rialto-Colton Basin also plots above the meteoric water line (Woolfenden, 1994). In contrast, water from wells in most parts of southern California plots slightly below the meteoric water line-possibly as a result of partial evaporation prior to recharge. Previous studies have shown that snow and snowmelt runoff typically plot above the meteoric water line (Magaritz and others, 1989). Water from most wells along section $A-A^{\prime}$ and in the adjacent Rialto-Colton Basin may plot above the meteoric water line because ground-water recharge in both areas is derived largely from the infiltration of streamflow derived from snowmelt runoff and winter rain in the nearby mountains. This water usually is not exposed to significant evaporation prior to recharge.

Irrigation return flow has been identified previously as an important source of recharge within the Bunker Hill Basin (San Bernardino Valley Municipal Water District, 1970; Hardt and Hutchinson, 1980). The isotopic composition of ground water from this source is different from that of ground water that has not been partly evaporated. The heaviest (least negative) waters sampled, especially with respect to $\delta^{18} \mathrm{O}$, were from observation wells screened near the water table or from samples collected near the top of the screened interval in wells $1 \mathrm{~N} / 4 \mathrm{~W}-34 \mathrm{G} 4$ and $1 \mathrm{~N} / 4 \mathrm{~W}$ $14 \mathrm{P} 1$ at depths of 320 and $420 \mathrm{ft}$, respectively. Water from these samples plots slightly to the right of the local ground-water line, along an evaporative trend line that intersects the local ground-water line near the median composition of water from most wells sampled (fig. 7). On the basis of these data, water near the water table appears to have been partly evaporated, and may 


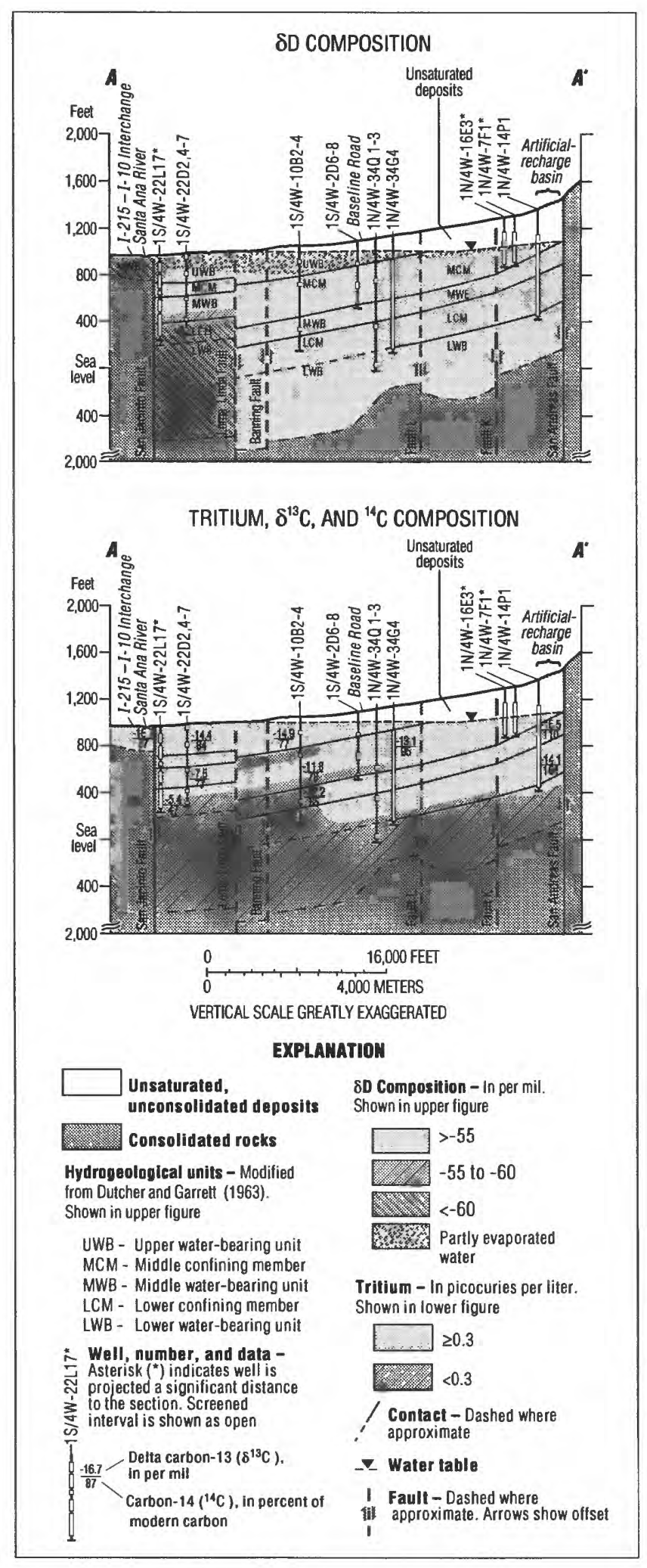

Figure 8. Isotopic (deuterium, tritium, carbon-13, and carbon-14) composition of water from selected wells along section $A-A^{\prime}$ in the San Bernardino area of southern California. have originated as irrigation return flow from past agricultural activity or present-day urban uses.

Similarly, imported water has been identified as an important source of ground-water recharge (Hardt and Freckleton, 1987). Imported water, both from northern California and from the Colorado River, has an isotopic composition that is different from that of native water. Water collected within well 1N/4W-34G4 at depths between 390 and 600 feet below land surface is isotopically lighter (more negative) than water from most other sampled wells (category $A$ in figure 7). The deep samples from well $1 \mathrm{~N} / 4 \mathrm{~W}-34 \mathrm{G} 4$, as well as the composite sample collected from the discharge pipe of the well, plot along a mixing line with samples of imported water from northern California (fig. 7) (data from Woolfenden, 1994, and from T.B. Coplen, II, U.S. Geological Survey, written commun., 1977). On the basis of these data, water discharged from well $1 \mathrm{~N} / 4 \mathrm{~W}$ -34G4 can be interpreted as a two-part mixture of about 75 percent native water and 25 percent imported water from northern California. Because samples collected within the well are affected by mixing within the well casing, water in the valley-fill aquifer between 390 and $600 \mathrm{ft}$ may contain an even greater percentage of imported water than indicated.

The largest difference in the isotopic composition of water from wells along section $A-A^{\prime}$ was found near the San Jacinto Fault-in particular at wells 1S/ 4W-22L17 and 1S/4W-22D4, and to some extent at well 1S/4W-22D5. Water from these wells was much lighter (more negative) than water from most other wells sampled and plots to the left and slightly below the meteoric water line in figure 7. The isotopic composition of water from these wells is similar to the isotopic composition of water in the Santa Ana River (Woolfenden, 1994; and Williams and Rodoni, University of California, Riverside, unpub. data, 1996). Water in the Santa Ana River is isotopically lighter than water from Devil Canyon and East Twin Creeks because the Santa Ana River drains areas of higher altitude in the San Bernardino Mountains.

Well $1 \mathrm{~S} / 4 \mathrm{~W}-22 \mathrm{~L} 17$ is located along the east bank of the Santa Ana River just upstream from the San Jacinto Fault. This production well is screened from 80 to $630 \mathrm{ft}$ below land surface (fig. 3). It is possible that pumping in this well has resulted in the infiltration of water from the Santa Ana River into underlying hydrogeologic units. Well 1S/4W-22D4 is a deep observation well that is part of a nearby multiple-well site (fig. 1). Shallower wells at this site yield water that is isotopi- 
cally heavier than water in the Santa Ana River. Thus, it is not likely that water from well 22D4 originated as infiltration of surface water. One possible explanation is that water from well 22D4 may have originated near the base of the San Bernardino Mountains, in the same manner as most other water along section $A-A^{\prime}$, but that the water may be very old and was recharged at a time when the climate was cooler and the isotopic composition of ground-water recharge was lighter. A second possible explanation is that water from well 22D4 was recharged at a different location, by water having a different isotopic composition, and is associated with a different ground-water flow system. Samples were collected and analyzed for tritium and carbon-14 to determine the age (time since recharge) of water from wells to evaluate which of these two hypotheses is more likely correct.

\section{Tritium}

Tritium $\left({ }^{3} \mathrm{H}\right)$ is a naturally occurring radioactive isotope of hydrogen that has a half-life of about 12.4 years. In this study, the activity of tritium was measured in picocuries per liter $(\mathrm{pC} / \mathrm{L})$; one $\mathrm{pC} / \mathrm{L}$ is equivalent to about 2.2 disintegrations of tritium per minute or about one tritium atom in $3.1 \times 10^{17}$ atoms of hydrogen. Prior to 1952 , the tritium concentration of precipitation in coastal southern California was about $6 \mathrm{pC} / \mathrm{L}$. About $800 \mathrm{~kg}$ of tritium was released to the atmosphere during 1952-62 (Michel, 1976) as a result of the atmospheric testing of nuclear weapons, and the tritium concentration of precipitation increased (fig. 9). Because tritium is part of the water molecule, tritium is not affected by reactions other than radioactive decay, and tritium is an excellent tracer of the movement of water on timescales ranging from 10 to less than 100 years before present. In this report, ground water having tritium activities less than the detection limit of $0.3 \mathrm{pC} / \mathrm{L}$ is considered to be water recharged before 1952 . Ground water having measurable tritium activity is considered to be water recharged after 1952.

Tritium activity in water from wells in this study ranged from less than the detection limit of $0.3 \mathrm{pC} / \mathrm{L}$, to $18 \mathrm{pC} / \mathrm{L}$. Measurable tritium was present in water samples throughout much of section $A-A^{\prime}$ from the recharge areas near the base of the San Bernardino Mountains to discharge areas near the San Jacinto Fault (fig. 8). On the basis of these data, the horizontal velocity of ground water moving through the UWB and MCM hydrogeo-

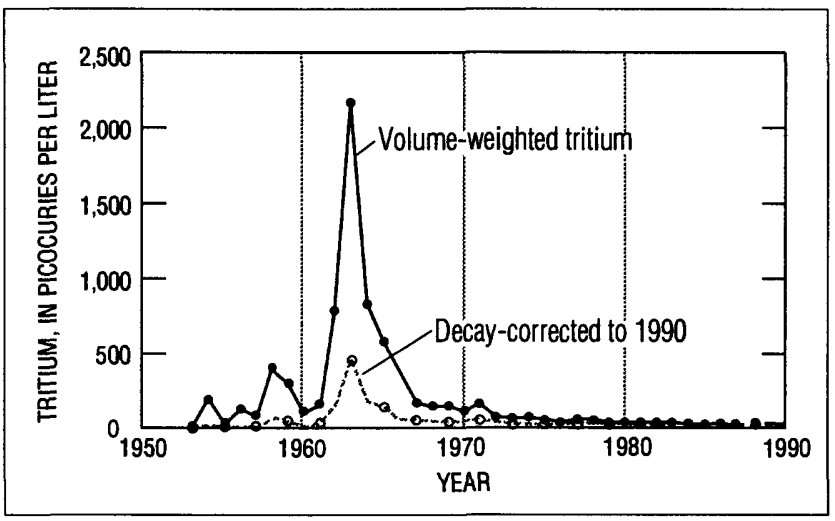

Figure 9. Tritium in precipitation at Santa Maria, California. (Data from International Atomic Energy Agency.)

logic units is greater than $2 \mathrm{ft} / \mathrm{d}$. This relatively high velocity is consistent with ground-water velocities calculated from contaminant movement in the Newmark area (D.L. Bane, URS Corporation, oral commun., 1996). In all of these calculations, it is assumed that ground water along section $A-A^{\prime}$ is recharged near the mountains and flows horizontally through the valley-fill aquifer to discharge areas near the San Jacinto Fault. It is possible that additional recharge occurs downgradient along the section and that this recharge water, which also contains tritium, moves vertically down into the valley-fill aquifer and commingles with water recharged near the mountains. If this alternate pathway is present, possibly through abandoned wells, then horizontal ground-water velocities could be much less than $2 \mathrm{ft} / \mathrm{d}$.

Measurable tritium was not present in water from deep wells downgradient from the recharge areas (fig. 8). These data suggest that ground-water movement through the MWB and LCM units is slower than in overlying units, probably less than $1 \mathrm{ft} / \mathrm{d}$, and that horizontal ground-water velocities decrease with depth. Vertical recharge to the deeper parts of the valley-fill aquifer in the downgradient part of the section is not likely given the absence of tritium in the deepest samples.

Water from deeper wells that does not contain measurable tritium was recharged prior to 1952 . The age (time since recharge) of this water cannot be determined on the basis of tritium data. Carbon-14 data were collected to determine the age of water from wells that did not contain tritium. 


\section{Carbon-14}

Carbon- $14\left({ }^{14} \mathrm{C}\right)$ is a naturally occurring radioactive isotope of carbon having a half-life of about 5,730 years. Carbon-14 data are expressed as percent modern carbon by comparing carbon-14 activities to the specific activity of National Bureau of Standards oxalic acid: 12.88 disintegrations per minute per gram of carbon in the year 1950 equals 100 percent modern carbon. Atmospheric testing of nuclear weapons produced carbon-14 along with tritium. As a result, carbon-14 activities may exceed 100 percent modern carbon in areas where ground water contains tritium. Carbon-14 activities are used to determine the age of ground water (time since recharge) on timescales ranging from recent to more than 20,000 years before present.

Carbon-14 is not part of the water molecule, and unlike tritium, carbon-14 activities are affected by chemical reactions that occur between dissolved constituents and the aquifer matrix. In this study, carbon$13\left({ }^{13} \mathrm{C}\right)$, a stable isotope of carbon, was used to evaluate, in a qualitative sense, the chemical reactions that occur within the valley-fill aquifer. Carbon-13 data are expressed as ratios in delta notation $(\delta)$ as per mil differences relative to the ratio of ${ }^{13} \mathrm{C}$ to ${ }^{12} \mathrm{C}$ in standard Peedee Belemnite (PDB) (Gonfiantini, 1978). Reactions within the aquifer may add carbon that does not contain carbon-14 to the dissolved phase or remove carbon that may contain carbon-14 from the dissolved phase. Thermodynamic and mass-balance simulations necessary to quantify changes in carbon-14 activity resulting from these reactions were not done as part of this study.

\section{Age of Ground Water}

Measured carbon-14 activities for 12 samples of water from 10 wells in the study area ranged from 110 to 47 percent modern carbon. In general, carbon-14 activities were highest in water from wells in the recharge areas, lower in water from wells in the discharge areas near the San Jacinto Fault, and lowest in water from deep wells that did not contain measurable tritium. For the three wells sampled that did not contain tritium (1S/4W-22D4, 1S/4W-10B2, and 1N/4W

$-34 \mathrm{Q} 1$ ), carbon-14 activities ranged from 84 to 47 percent modern carbon. Neglecting the chemical reactions that occur within the aquifer and assuming only radioactive decay and an initial carbon-14 activity of 90 percent modern carbon, the calculated ages of water from these wells range from about 500 years before present for water from wells $1 \mathrm{~S} / 4 \mathrm{~W}-10 \mathrm{~B} 2$ and $1 \mathrm{~N} / 4 \mathrm{~W}-34 \mathrm{Q} 1$ to about 5,000 years before present for well 1S/4W-22D4.

Measured $\delta^{13} \mathrm{C}$ composition of water from wells ranged from -5.4 to -16.6 per mil. The $\delta^{13} \mathrm{C}$ values were heavier (less negative) in water from deep wells near the downgradient end of section $A-A^{\prime}$. Heavy $\delta^{13} \mathrm{C}$ values in water from wells are consistent with the reaction of ground water with aquifer cements such as calcite. In desert aquifers to the east of the study area, calcite cements typically have heavy $\delta^{13} \mathrm{C}$ values, about -4 per mil (Izbicki and others, 1995). In two analyses of aquifer cements done on drill cuttings from well $1 \mathrm{~N} / 4 \mathrm{~W}-34 \mathrm{Q} 1$, the $\delta^{13} \mathrm{C}$ value was -6.7 per mil. The $\delta^{13} \mathrm{C}$ values were lighter (more negative) in water from wells open to the freshwater marsh deposits and from alluvial deposits in discharge areas near the San Jacinto Fault. Light $\delta^{13} \mathrm{C}$ values in water from wells is consistent with the reaction of ground water with organic material in the valley-fill aquifer. In two analyses of organic material in drill cuttings from well $1 \mathrm{~N} / 4 \mathrm{~W}$ $34 \mathrm{Q} 1$, the $\delta^{13} \mathrm{C}$ values were -29.5 and -26.5 per mil. These values are consistent with $\delta^{13} \mathrm{C}$ values for nonmarine organic material. As described earlier in this report, ground-water chemistry is affected by organic material, particularly near the San Jacinto Fault in the vicinity of the former marshland.

On the basis of carbon-13 data, the carbon-14 activity of water from the deep wells that do not contain tritium, as well as water from other sampled wells in the area, has been affected by reactions with aquifer materials. As a result, actual ages of water from wells are probably younger than the ages presented in this report. Using thermodynamic and mass-balance simulations, Izbicki and others $(1992,1995)$ demonstrated that corrections for chemical reactions that occur within an aquifer can result in an interpreted groundwater age that is as much as 30 percent less than the age calculated by assuming only radioactive decay.

\section{Sources of Older Ground Water}

Studies of oxygen, hydrogen, and carbon isotopes done in other ground-water basins can help to resolve questions about ground-water flow in the Bunker Hill Basin-especially questions about the source of water from well 1S/4W-22D4. Water from the well is isotopically lighter with respect to $\delta \mathrm{D}$ and $\delta^{18} \mathrm{O}$ than water from most other sampled wells and, on the basis of carbon-14 data, is the oldest water from the wells 
sampled. As discussed previously, water from this well may be very old and recharged at a time when the climate was cooler and the isotopic composition of ground-water recharge was lighter, or the water may have been recharged at a different location and is associated with a different ground-water flow system.

Changes in the stable isotopic composition of ground water with increasing age were evaluated in the adjacent Mojave River Basin and the nearby Santa Clara-Calleguas Basin by Izbicki and others (1992, 1995). Some ground water in those basins, especially water from deep wells near the downgradient end of long flow paths through the aquifers, was found to have been recharged more than 20,000 years ago. This water is much older than ground water in the Bunker Hill Basin. On average, the $\delta^{18} \mathrm{O}$ composition of ground water in the Santa Clara-Calleguas and Mojave Basins decreased by about 0.05 to 0.07 per mil per 1,000 years as a result of climate change during that period.

Although this is an average rate, and the decrease in $\delta^{18} \mathrm{O}$ composition probably has not been uniform during the last 20,000 years, data from these nearby basins can serve as a baseline from which to evaluate observed changes in isotopic composition of water from wells along section $A-A^{\prime}$.

On the basis of these data, the expected $\delta^{18} \mathrm{O}$ isotopic composition of water recharged less than 5,000 years ago near the base of the San Bernardino Mountains would not be more than 0.25 to 0.35 per mil lighter than that of present-day recharge from Devil Canyon and East Twin Creeks. In contrast, water from well 1S/4W-22D4 is more than 0.7 per mil lighter than present-day recharge from these sources and is more similar in isotopic composition to water from the Santa Ana River. This result suggests that water from well 1S/4W-22D4 may not have been recharged near the base of the San Bernardino Mountains by infiltration of surface water from Devil Canyon or East Twin Creeks and may be part of a different flow path, oblique to section $A-A^{\prime}$. Possible sources for this recharge include infiltration of runoff from the Santa Ana River or Lytle Creek. These streams drain areas of higher altitude in the San Bernardino Mountains and San Gabriel Mountains, respectively (fig. 1).

\section{DISCUSSION OF CHEMICAL AND ISOTOPIC DATA}

In alluvial aquifers undisturbed by human development, the paths of ground-water flow are relatively simple: ground water flows from natural recharge areas to natural discharge areas, and ground-water levels vary in a predictable manner with depth. However, as these basins are developed and water is pumped from wells, the paths of ground-water flow change-horizontally and vertically, and with time. As a result, in basins with extensive ground-water pumping, such as the Bunker Hill Basin, it can be difficult to conceptualize, much less predict, the complex pattern of threedimensional ground-water flow using two-dimensional ground-water-level data. The presence of contaminants in many of these aquifers that are used for public supply requires a knowledge of three-dimensional groundwater flow in order to understand the movement of the contaminants and to design effective mitigation strategies. Water-chemistry and isotopic data can provide knowledge about the source, movement, and age of ground water that is not readily obtainable from more traditional water-level and water-quality data-especially when the chemical and isotopic data are collected from known depths and are representative of specific hydrogeologic units within the aquifer.

In the Bunker Hill Basin, measurable differences, both areally and with depth, were found in the chemical and isotopic composition of water from observation wells completed at different depths along a north-south section $\left(A-A^{\prime}\right)$ through the basin. Similarly, measurable differences were found in water collected from different depths within two production wells (1N/ 4W-34G4 and 1N/4W-14P1, table 2). Depth-dependent, water-quality data for these production wells were collected at full-production pumping rates. The vertical differences in water quality within the production wells were interpreted with the aid of concurrently collected flowmeter data and were found to be comparable to differences expected on the basis of waterchemistry and isotopic data from nearby observation wells.

In contrast, virtually no differences in waterchemistry or isotopic data were observed in water samples collected during packer tests done in production well 1S/4W-22L17 (table 2), even though nearby observation wells had large differences in water chemistry and isotopic composition. These data suggest that the data collected during the packer tests were not rep- 
resentative of ground-water quality at different depths within the aquifer. The inflatable packers isolated an interval within the casing, but they did not isolate a comparable interval within the valley-fill aquifer. Vertical flow through the gravel pack outside the casing, effectively short-circuiting the packers, seems a likely explanation for the nearly identical water-quality data. On the basis of these results, packer tests-although commonly accepted in the water-well industry-may not be an effective technique to collect depth-dependent water-quality samples from gravel-packed wells in alluvial aquifers.

Differences in the chemical and isotopic composition of water from streams and wells along the study section were useful in identifying ground-water flow paths. Ground water originating as recharge from Devil Canyon Creek has slightly different chemistry than does ground water originating as recharge from East Twin Creek. These differences mimic the differences in the major-ion chemistry and, to some degree, the traceelement chemistry found in samples of base flow from Devil Canyon Creek and from East Twin Creek.

These two flow paths appear to areally converge between the bedrock outcrops on either side of the study section (Shandin Hills and Perris Hill), commingle, and continue toward discharge areas near the San Jacinto Fault. At least some of the ground water recharged from East Twin Creek may follow a deeper flow path and maintain a distinct chemical composition. Geochemical evidence for a deeper flow path was presented originally by Duell and Schroeder (1989); however, they did not have the depth-dependent samples necessary to trace this flow path through the valley-fill aquifer. Some of the observed differences in chemistry may result from reactions of ground water with aquifer materials or from inflow of ground water from the bedrock surrounding and underlying the valley-fill aquifer.

Isotopic data indicate that water in well $1 \mathrm{~S} / 4 \mathrm{~W}$ -22D4 did not originate as recharge from either Devil Canyon Creek or East Twin Creek and did not move along either of the flow paths identified in section $A-A^{\prime}$. The location of the well relative to stream courses suggests that recharge may have originated from Lytle Creek or the Santa Ana River, each of which has an average discharge more than five times the combined discharge of Devil Canyon and East Twin Creeks.

The presence of tritium in water from many of these wells suggests that recent (post 1952) ground- water recharge has moved relatively rapidly (as fast as $2 \mathrm{ft} / \mathrm{d}$ in some areas) through the valley-fill aquifer and to relatively great depths (more than $800 \mathrm{ft}$ below land surface) when compared to the results of similar studies in other parts of California (Izbicki and others, 1992, 1995; Izbicki, 1996; Izbicki and Martin, 1997). On the basis of carbon-14 data, the ages (time since recharge) of water from wells ranged from recent to about 5,000 years before present. Because these ages are not corrected for chemical reactions that occur between ground water and the aquifer materials, the actual age of water from wells probably is less.

Water with an age greater than 10,000 years before present, which is typical of water from deep wells in alluvial aquifers in other parts of California, was not observed in wells along the study section. The rapid movement and comparatively deep circulation of water in this part of the Bunker Hill Basin may result from a combination of geologic and hydrologic factors such as: (1) the comparatively large quantity of water available for ground-water recharge along the base of the San Bernardino Mountains; (2) the presence of coarse-grained deposits with minimal fine-grained material near the base of the mountains; (3) the geometry of this part of the valley-fill aquifer whereby recharge from a long stretch of the mountain front is forced between two bedrock outcrops (Shandin Hills and Perris Hill); (4) the large quantity of ground water pumped from the valley-fill aquifer, helping to accelerate the movement of ground water; (5) the enhanced downward movement of ground water caused by a reversal of ground-water gradient; and (6) the presence of many vertical conduits of ground-water flow, including more than 800 abandoned wells.

\section{SUMMARY AND CONCLUSIONS}

In the Bunker Hill Basin of southern California, measurable differences, both areally and with depth, were found in the chemical and isotopic composition of water from observation wells completed at different depths along a north-south section through the basin. Similarly, measurable differences were found in water collected, under pumping conditions, from different depths within two production wells (1N/4W-34G4 and $1 \mathrm{~N} / 4 \mathrm{~W}-14 \mathrm{P} 1)$ near the section. In contrast, virtually no differences in water-chemistry or isotopic data were observed in water samples collected during packer 
tests done in a production well (1S/4W-22L17) near the south end of the section, even though nearby wells had large differences in water chemistry and isotopic composition. These data suggest that data collected during packer tests were not representative of groundwater quality at different depths within the valley-fill aquifer.

Results of chemical analysis indicate that three general zones of water quality are present along section $A-A^{\prime}:$ : (1) an oxygenated zone near the base of the San Bernardino Mountains, (2) an oxygen-depleted zone near the San Jacinto Fault, and (3) a deeper zone that is oxygenated near the base of the mountains and oxygen-depleted farther from the mountains. Water in this third zone also is characterized by fluoride concentrations greater than $1 \mathrm{mg} / \mathrm{L}$ and by a general waterquality composition similar to that of base flow in East Twin Creek. Differences in the chemical and isotopic composition of water from streams and wells were useful in identifying ground-water flow paths created by recharge from Devil Canyon Creek and East Twin Creek. These two flow paths appear to converge areally between bedrock outcrops (Shandin Hills and Perris Hill) on either side of the study section, commingle, and continue toward discharge areas near the San Jacinto Fault. At least some of the ground water recharged from East Twin Creek may follow a deeper flow path and maintain a distinct chemical composition. Isotopic data indicate that water in well $1 \mathrm{~S} / 4 \mathrm{~W}$ 22D4 did not originate as recharge from either Devil Canyon Creek or East Twin Creek and may have originated as recharge from either Lytle Creek or the Santa Ana River.

The presence of tritium in water from many of these wells suggests that recent (post 1952) groundwater recharge has moved relatively rapidly (as fast as $2 \mathrm{ft} / \mathrm{d}$ in some areas) through the valley-fill aquifer and to relatively great depths (more than $800 \mathrm{ft}$ below land surface) when compared to the results of similar studies in other parts of southern California. On the basis of carbon-14 data, the ages (time since recharge) of water from wells ranged from recent to about 5,000 years before present. Because these ages are not corrected for chemical reactions that occur between ground water and the aquifer materials, the actual age of water from wells probably is less. The rapid movement and comparatively deep circulation of water in this part of the Bunker Hill Basin along the study section may result from a combination of geologic and hydrologic factors such as: (1) the comparatively large quantity of water available for ground-water recharge along the base of the San Bernardino Mountains; (2) the presence of coarse-grained deposits near the base of the mountains; (3) the geometry of this part of the valleyfill aquifer whereby recharge from a long stretch of the mountain front is forced between two bedrock outcrops (Shandin Hills and Perris Hill); (4) the large quantity of ground water pumped from the valley-fill aquifer, helping to accelerate movement of ground water; (5) the enhanced downward movement of ground water caused by a reversal of ground-water gradient; and (6) the presence of many vertical conduits of ground-water flow, including more than 800 abandoned wells.

\section{REFERENCES CITED}

Craig, H., 1961, Isotopic variation in meteoric waters: Science, v. 133, p. 1,702-1,703.

Driscoll, F.G., 1986, Groundwater and wells, second edition: Johnson Filtration Systems, Inc., Saint Paul, Minnesota, $1,089 \mathrm{p}$.

Duell, F.W., and Schroeder, R.A., 1989, Appraisal of groundwater quality in the Bunker Hill Basin of San Bernardino Valley, California: U.S. Geological Survey WaterResources Investigations Report 88-4203, 69 p.

Dutcher, L.C., and Garrett, A.A., 1963, Geologic and hydrologic features of the San Bernardino area, California: U.S. Geological Survey Water-Supply Paper 1419, 114 p.

Earth Technology Corporation, 1993, Off-base trichloroethylene plume investigation, phase II draft report: Norton Air Force Base, Central base area operable unit, Remedial investigation report supplement: Alexandria, Virginia, 7 sections.

Eccles, L.A., 1979, Ground-water quality in the upper Santa Ana River basin, southern California: U.S. Geological Survey Water-Resources Investigations Report 79-113, $51 \mathrm{p}$.

Gonfiantini, R., 1978, Standards for stable isotope measurements in natural compounds: Nature, v. 271, p. 534536.

Gossell, M.A., Hanson, R.T., Izbicki, J.A., and Nishikawa, T., 1995, Application of impeller-flowmeter and discrete water-sampling techniques for improved groundwater well construction (abs.): EOS, v. 76, no. 46, p. 182.

Hardt, W.F., and Freckleton, J.R., 1987, Aquifer response to recharge and pumping, San Bernardino ground-water basin, California: U.S. Geological Survey WaterResources Investigations Report 86-4140, $69 \mathrm{p}$. 
Hardt, W.F., and Hutchinson, C.B., 1980, Development and use of a mathematical model of the San Bernardino Valley ground-water basin, California: U.S. Geological Survey Open-File Report 80-576, 80 p.

International Atomic Energy Agency, 1981, Stable isotope hydrology: Deuterium and oxygen-18 in the water cycle: Technical Reports Series No. 210, 337 p.

Izbicki, J.A., 1991, Chloride sources in a California coastal aquifer, in Peters, Helen, ed., Ground water in the Pacific Rim Countries: American Society of Civil Engineers, IR Div/ASCE, Proceedings, p. 71-77.

Izbicki, J.A., 1996, Use of $\delta^{18} \mathrm{O}$ and $\delta \mathrm{D}$ to define seawater intrusion, in Bathala, C.T., ed., North American Water and Environment Congress, Anaheim, California, June 23-28, Proceedings: New York, American Society of Civil Engineers, 1 CD-ROM.

Izbicki, J.A., and Martin, Peter, 1997, Use of isotopic data to evaluate recharge and geologic controls on the movement of ground water in Las Posas Valley, Ventura County, California: U.S. Geological Survey WaterResources Investigations Report 97-4035, 12 p.

Izbicki, J.A., Martin, Peter, and Michel, R.L., 1995, Source, movement, and age of groundwater in the upper part of the Mojave River basin, California, USA, in Adar, E.M., and Leibundgut, Christian, Application of tracers in arid zone hydrology, Vienna, Austria, August 22-26, 1994, Proceedings: Wallingford, England, International Association of Hydrological Sciences, IAHS No. 215, p. 43-56.

Izbicki, J.A., Michel, R.L., and Martin, Peter, $1992,{ }^{3} \mathrm{H}$ and ${ }^{14} \mathrm{C}$ as tracers of ground water recharge, in Engman, Ted, Saving a threatened resource-in search of solutions, Baltimore, Maryland, August 2-6, 1992, Proceedings: New York, American Society of Civil Engineers, IR Div/ASCE, p. 122-127.
Klein, J.M., and Bradford, W.L., 1979, Distribution of nitrate and related nitrogen species in the unsaturated zone, Redlands and vicinity, San Bernardino County, California: U.S. Geological Survey Water-Resources Investigations Report 79-60, $81 \mathrm{p}$.

Klein, J.M., and Bradford, W.L., 1980, Distribution of nitrate in the unsaturated zone, Highland-East Highlands area, San Bernardino County, California: U.S. Geological Survey Water-Resources Investigations Report 80-48, $70 \mathrm{p}$.

Magaritz, M., Aravena, R., Pena, H., Suzuki, O., and Grilli, A., 1989, Water chemistry and isotope study of streams and springs in northern Chile: Journal of Hydrology, v. 108, p. 323-341.

Michel, R.L.,1976, Tritium inventories of the world's oceans and their implications: Nature, v. 263, p. 103-106.

Piper, A.M., 1944, A graphic procedure in the geochemical interpretation of water analyses: American Geophysical Union Transactions, v. 25, p. 914-923.

San Bernardino Valley Municipal Water District, 1970, San Bernardino basin safe yield study: Volumes 1-4.

U.S. Environmental Protection Agency, 1994, Drinking water standards and health advisories table: U.S Environmental Protection Agency, Region IX, San Francisco, California, 25 p.

Woolfenden, L.R., 1994, Oxygen-18, deuterium, and tritium as tracers of imported water in the Rialto-Colton basin, California, in Marston, R.A. and Hasfurther, V.R., Effects of human-induced changes on hydrologic systems: American Water Resources Association, p. 923-932. 
Table 2 
Table 2. Chemical and isotopic analyses of water from selected wells in the San Bernardino area of southern California [State well No.; See Well-Numbering System in text. Altitude of land surface datum in feet above sea level; ft, foot; $\mu \mathrm{S} / \mathrm{cm}$, microsiemen per centimeter at $25^{\circ} \mathrm{C}$; mg/L, milligram per liter; $\mu \mathrm{g} / \mathrm{L}$, microgram per liter; $\mathrm{pC} / \mathrm{L}$, picocurie per liter; per mil, parts per thousand; ${ }^{\circ} \mathrm{C}$, degree Celsius; - , no data]

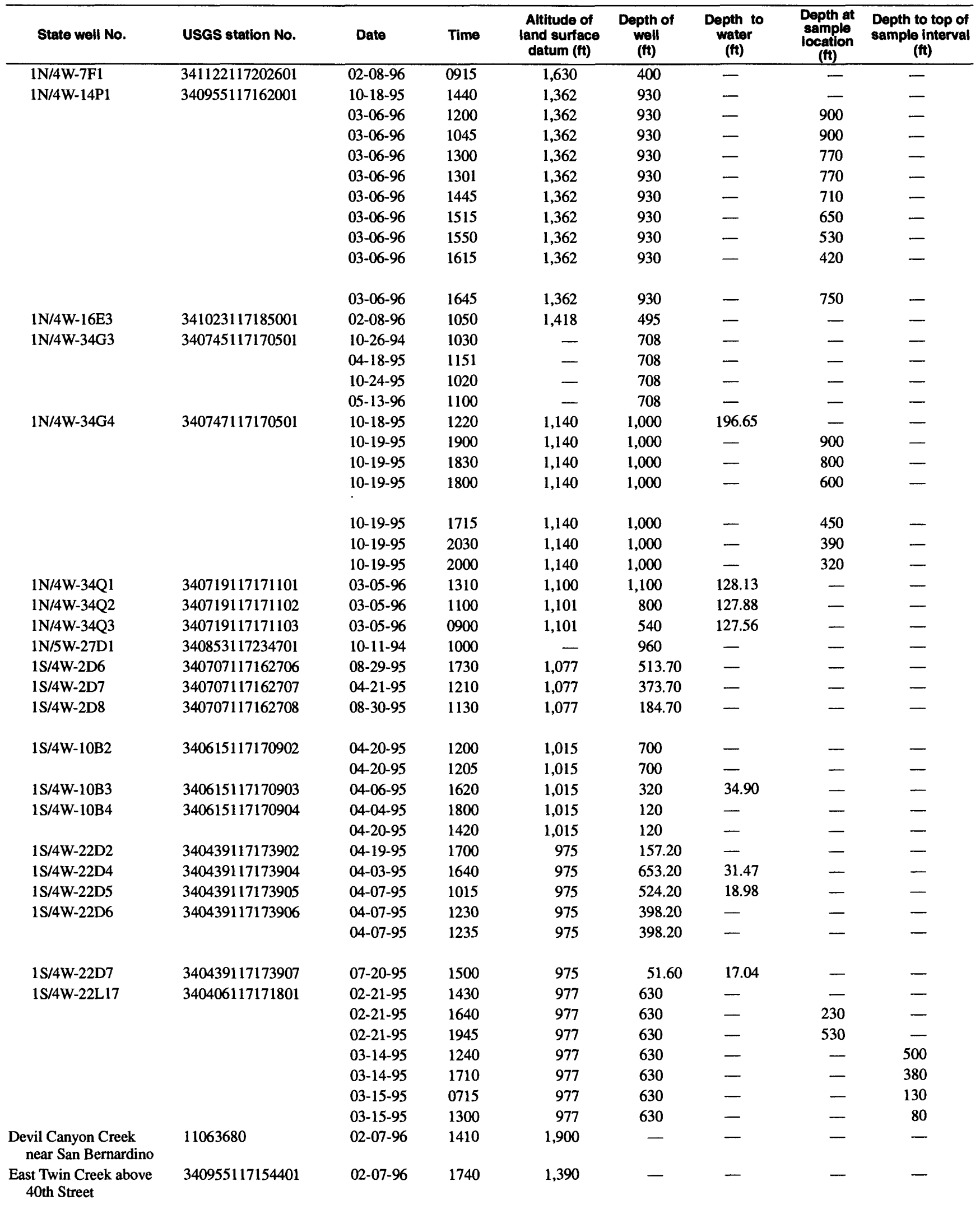


Table 2. Chemical and isotopic analyses of water from selected wells in the San Bernardino area of southern California -Continued

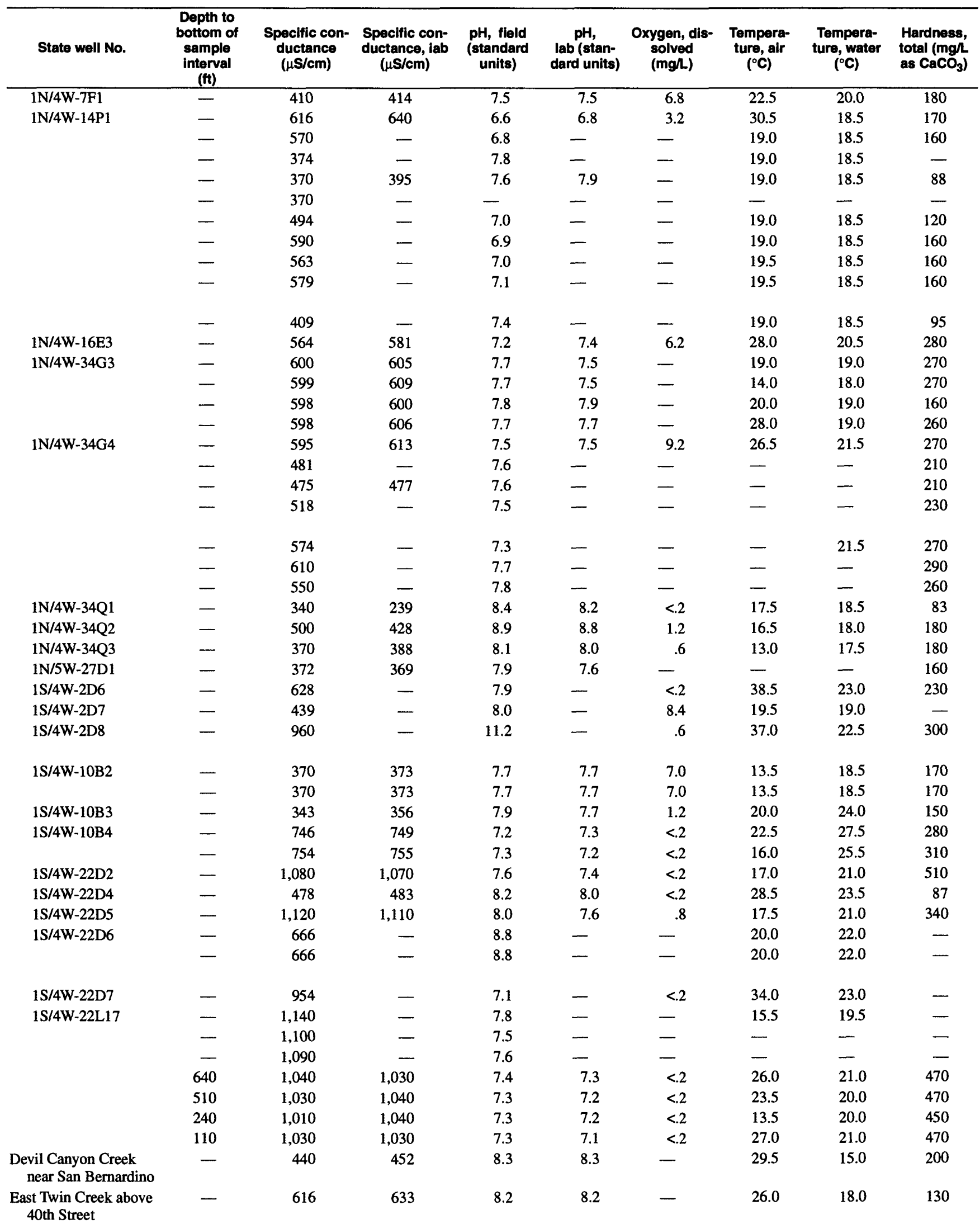


Tabie 2. Chemical and isotopic analyses of water from selected wells in the San Bernardino area of southern California-Continued

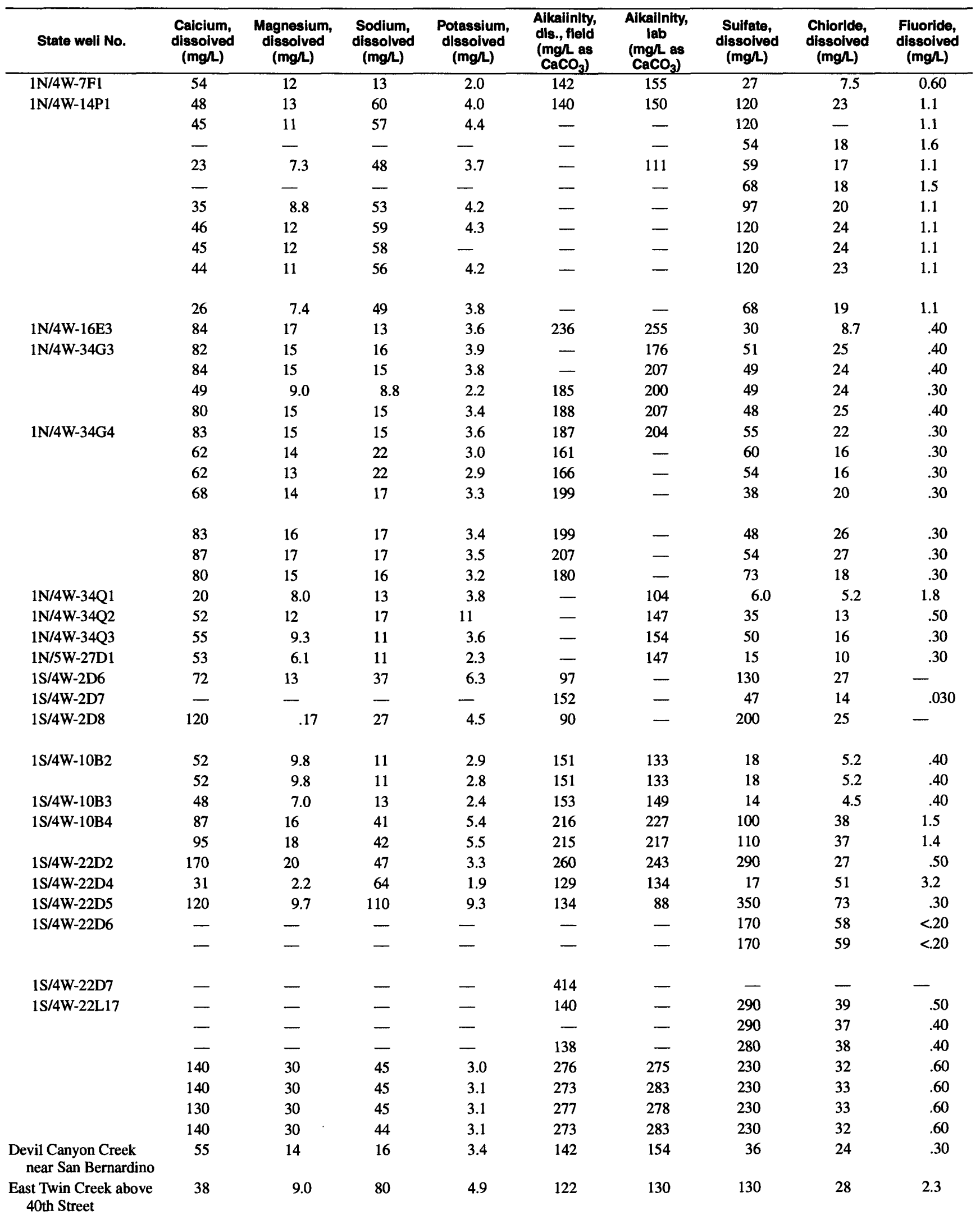


Table 2. Chemical and isotopic analyses of water from selected wells in the San Bernardino area of southern California-Continued

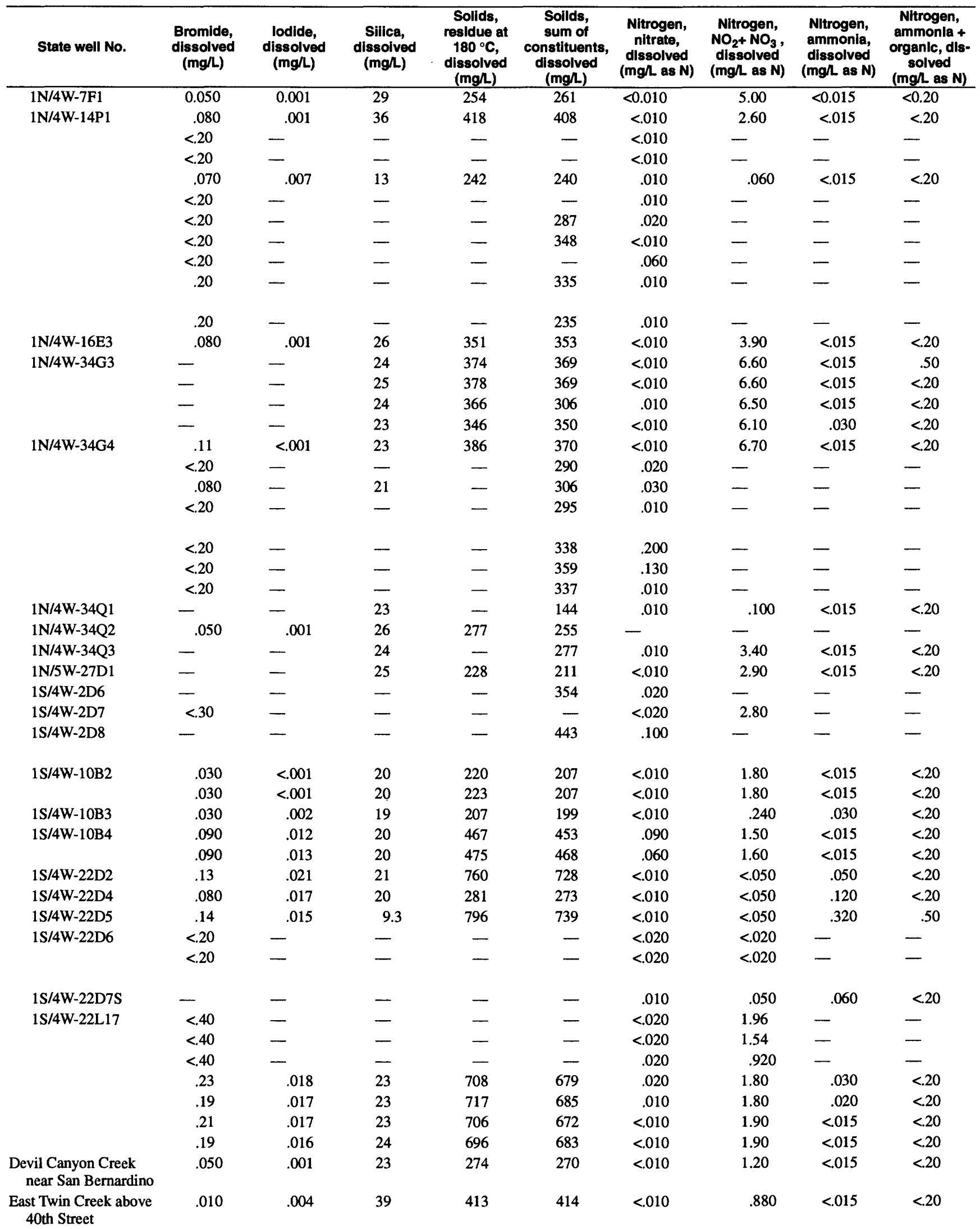


Table 2. Chemical and isotopic analyses of water from selected wells in the San Bernardino area of southern California-Continued

\begin{tabular}{|c|c|c|c|c|c|c|c|}
\hline State weli No. & $\begin{array}{l}\text { Phosphorus, } \\
\text { dissolved } \\
\text { (mgh) }\end{array}$ & $\begin{array}{l}\text { Phosphate, } \\
\text { ortho, } \\
\text { dissoived } \\
\text { (mgh) }\end{array}$ & $\begin{array}{c}\text { Arsenic, } \\
\text { dissoived } \\
(\mu g / L)\end{array}$ & $\begin{array}{l}\text { Barium, } \\
\text { dissolved } \\
(\mu g / L)\end{array}$ & $\begin{array}{l}\text { Boron, } \\
\text { dissoived } \\
(\mu g / L)\end{array}$ & $\begin{array}{l}\text { Iron, } \\
\text { dissoived } \\
(\mu g \Omega)\end{array}$ & $\begin{array}{l}\text { Lithium, } \\
\text { dissolved } \\
(\mu g /))\end{array}$ \\
\hline $1 \mathrm{~N} / 4 \mathrm{~W}-7 \mathrm{~F} 1$ & $<0.010$ & 0.06 & $<1$ & 100 & 10 & 4.0 & $<10$ \\
\hline \multirow[t]{10}{*}{$1 \mathrm{~N} / 4 \mathrm{~W}-14 \mathrm{P} 1$} & $<.010$ & .03 & 1 & 100 & 440 & 15 & - \\
\hline & - & - & - & - & 430 & 70 & - \\
\hline & - & - & - & - & - & - & - \\
\hline & $<.010$ & - & 2 & $<100$ & 300 & 510 & 30 \\
\hline & - & - & - & - & - & - & - \\
\hline & - & - & - & - & 360 & 260 & - \\
\hline & - & - & - & - & 430 & 260 & - \\
\hline & - & - & - & - & 420 & 150 & - \\
\hline & - & - & - & - & 430 & 160 & - \\
\hline & - & - & - & - & 300 & 330 & - \\
\hline $1 \mathrm{~N} / 4 \mathrm{~W}-16 \mathrm{E} 3$ & $<.010$ & .03 & 1 & 100 & 20 & $<3.0$ & $<10$ \\
\hline \multirow[t]{4}{*}{$1 \mathrm{~N} / 4 \mathrm{~W}-34 \mathrm{G} 3$} & $<.010$ & .03 & - & - & 40 & $<3.0$ & - \\
\hline & $<.010$ & .06 & - & - & 50 & $<3.0$ & - \\
\hline & $<.010$ & .03 & - & - & 50 & $<3.0$ & - \\
\hline & .040 & .06 & - & - & 40 & $<3.0$ & - \\
\hline \multirow[t]{7}{*}{$1 \mathrm{~N} / 4 \mathrm{~W}-34 \mathrm{G} 4$} & $<.010$ & .03 & 1 & 200 & 30 & $<3.0$ & - \\
\hline & - & - & - & - & 50 & 90 & - \\
\hline & - & - & $<1$ & $<500$ & 40 & $<10$ & - \\
\hline & - & - & - & - & 40 & 20 & - \\
\hline & - & - & - & - & 30 & 70 & - \\
\hline & - & - & - & - & 40 & 10 & - \\
\hline & - & - & - & - & 40 & $<10$ & - \\
\hline $1 \mathrm{~N} / 4 \mathrm{~W}-34 \mathrm{Q} 1$ & $<.010$ & .03 & - & - & 10 & 13 & - \\
\hline $1 \mathrm{~N} / 4 \mathrm{~W}-34 \mathrm{Q} 2$ & - & - & 2 & $<100$ & 30 & 3.0 & $<10$ \\
\hline $1 \mathrm{~N} / 4 \mathrm{~W}-34 \mathrm{Q} 3$ & $<.010$ & .06 & - & - & 10 & 5.0 & - \\
\hline $1 \mathrm{~N} / 5 \mathrm{~W}-27 \mathrm{D} 1$ & - & .09 & - & - & 20 & 4.0 & - \\
\hline 1S/4W-2D6 & - & - & - & - & - & - & - \\
\hline $1 \mathrm{~S} / 4 \mathrm{~W}-2 \mathrm{D} 7$ & $<.400$ & - & - & - & - & - & - \\
\hline 1S/4W-2D8 & - & - & - & - & - & - & - \\
\hline \multirow[t]{2}{*}{$1 \mathrm{~S} / 4 \mathrm{~W}-10 \mathrm{~B} 2$} & $<.010$ & - & 1 & 33 & 10 & 30 & - \\
\hline & $<.010$ & - & 1 & 32 & 10 & 25 & - \\
\hline $1 \mathrm{~S} / 4 \mathrm{~W}-10 \mathrm{~B} 3$ & $<.010$ & .03 & $<1$ & 44 & 50 & 140 & - \\
\hline \multirow[t]{2}{*}{ 1S/4W-10B4 } & $<.010$ & - & $<1$ & 66 & 520 & 260 & - \\
\hline & $<.010$ & - & $<1$ & 68 & 480 & 250 & - \\
\hline $1 \mathrm{~S} / 4 \mathrm{~W}-22 \mathrm{D} 2$ & $<.010$ & - & 3 & 140 & 280 & 1,200 & - \\
\hline $1 \mathrm{~S} / 4 \mathrm{~W}-22 \mathrm{D} 4$ & .010 & - & 1 & 25 & 940 & 300 & - \\
\hline 1S/4W-22D5 & $<.010$ & - & $<1$ & 120 & 300 & 940 & - \\
\hline \multirow[t]{2}{*}{ 1S/4W-22D6 } & $<.400$ & - & - & - & - & - & - \\
\hline & $<.400$ & - & - & - & - & - & - \\
\hline $1 \mathrm{~S} / 4 \mathrm{~W}-22 \mathrm{D} 7$ & $<.010$ & - & - & - & - & - & - \\
\hline \multirow[t]{7}{*}{ 1S/4W-22L 17} & 1.60 & - & - & - & - & - & - \\
\hline & .700 & - & - & - & - & - & - \\
\hline & 1.20 & - & - & - & - & - & - \\
\hline & .010 & - & $<1$ & 76 & 120 & 1,300 & - \\
\hline & $<.010$ & - & $<1$ & 77 & 130 & 1,000 & - \\
\hline & .020 & - & $<1$ & 77 & 130 & 620 & - \\
\hline & $<.010$ & - & $<1$ & 78 & 110 & 320 & - \\
\hline $\begin{array}{l}\text { Devil Canyon Creek } \\
\text { near San Bernardino }\end{array}$ & $<.010$ & - & $<1$ & $<100$ & 40 & 4.0 & $<10$ \\
\hline $\begin{array}{l}\text { East Twin Creek above } \\
\text { 40th Street }\end{array}$ & $<.010$ & .03 & 19 & $<100$ & 590 & 40 & 70 \\
\hline
\end{tabular}


Tabie 2. Chemical and isotopic analyses of water from selected wells in the San Bernardino area of southern California-Continued

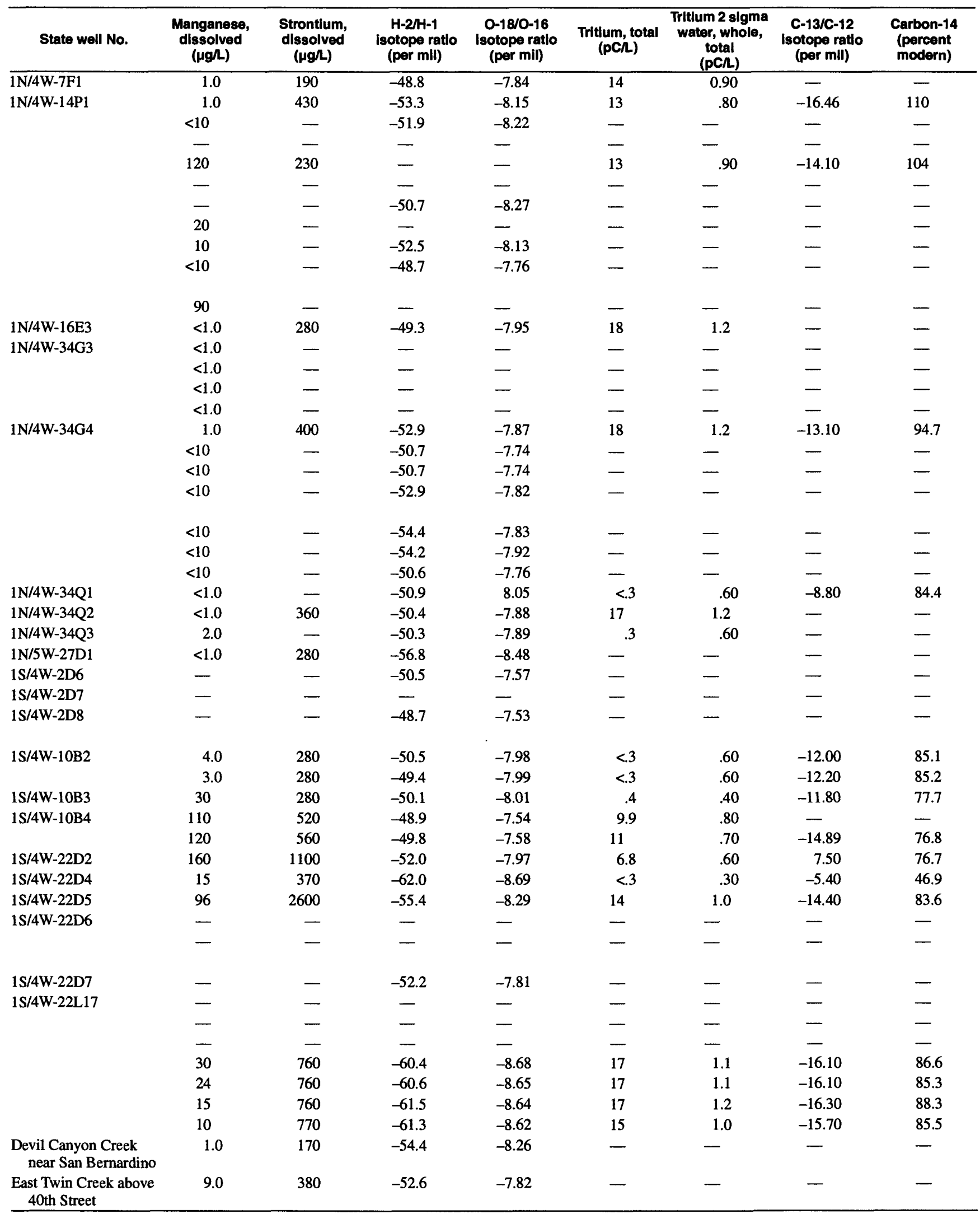

